\title{
REASONS FOR ENTREPRENEURS TO PARTICIPATE IN INTER ORGANIZATIONAL SOCIAL NETWORKS IN TURKEY
}

DOI: 10.17261/Pressacademia.2021.1450

RJBM- V.8-ISS.3-2021(3)-p.181-197

\section{Murat Cubukcu}

Bursa Uludag University, Institute of Social Sciences, Bursa, Turkey. mcubukcu16@gmail.com, ORCID: 0000-0001-9170-4852

\begin{tabular}{l}
\hline Date Received: May 9, $2021 \quad$ Date Accepted: September 12, 2021 \\
\hline To cite this document \\
Cubukcu, M., (2021). Reasons for entrepreneurs to participate in Inter organizational social networks in Turkey. Research Journal of Business and \\
Management (RJBM), 8(3), 181-197. \\
Permanent link to this document: http://doi.org/10.17261/Pressacademia.2021.1450 \\
Copyright: Published by PressAcademia and limited licensed re-use rights only.
\end{tabular}

\section{ABSTRACT}

Purpose- In this study, it is aimed to determine the reasons for the participation of business people in social networks of organizations that are among the first 500 industrial enterprises of ISO in Turkey.

Methodology- As a research method, quantitative research methods were used, based on the research data, in accordance with the research question. A theoretical framework was developed to explain the research questions based on the discussions in the literature, and the reasons for joining the networks were created. These 10 reasons were asked to Turkish business people via a questionnaire in order to support your conclusions about networks.

Findings- There are some results specific to Turkey in the reasons for business people to join the networks. The effect of locality is seen in the formation of network relations in Turkey and the reasons for Turkish business people to join these networks. It has been determined that business people with similar profiles gather in similar networks.

Conclusion- It is seen that business people are in convergence, groupings and clusters related to each other according to the context, such as living and working in the same region, gender, sports clubs, fellow countrymen and professional solidarity networks. It has been determined that Turkish business people are mostly involved in social networks that enable them to come together with people with similar qualifications. The results of the research show that entrepreneurs can establish established relationships with other business people with common characteristics. The effect of embedded in Turkey produces different motives and results compared to the West.

Keywords: Networks, social networks, inter-organizational networks, reasons for joining networks, embeddedness.

JEL Codes: M10, M12, M14.

\section{TÜRKIYE'DE IŞ INSANLARININ ÖRGÜTLER ARASI SOSYAL AĞLARA KATILMA NEDENLERi}

\section{ÖZET}

Amaç - Bu çalışmada, Türkiye'de iso ilk 500 sanayi kuruluşu içerisinde yer alan kuruluşların iş insanlarının sosyal ağlara katılma nedenlerinin belirlenmesi amaçlanmaktadır.

Metodoloji - Araştırma yöntemi olarak, araştırma sorusu gereği, araştırma verilerine dayanılarak niceliksel araştırma yöntemleri kullanılmıştır. Literatürdeki tartışmalardan yola çıkarak oluşturulan araştırma sorularını açıklamaya yönelik kuramsal çerçeve geliştirilmiş ve ağlara katılma nedenlerine yönelik gerekçeler oluşturulmuştur. Bu belirlenen 10 gerekçe, ağlara ilişkin çıkarımlarımızı desteklemek amacıyla Türk iş insanlarına anket formu yoluyla sorulmuştur.

Bulgular - İş insanlarının ağlara katılma gerekçelerinde Türkiye'ye özgü birtakım sonuçlar görülmektedir. Türkiye'de ağ ilişkilerinin oluşumunda ve Türk iş insanlarının bu ağlara katılma gerekçelerinde yerelliğin etkisi görülmektedir. Benzer profildeki iş insanlarının benzer ağlarda toplandıkları tespit edilmiştir.

Sonuç - İş insanlarının aynı bölgede yaşama ve çalışma, cinsiyet, tutulan spor kulübü, hemşehri ve mesleki dayanışma ağları gibi bağlama göre birbirleriyle bağlantılı yakınlaşmalar, gruplaşmalar ve kümelenmeler içerisinde bulundukları görülmektedir. Türk iş insanlarının da ağırlıklı olarak kendileri ile benzer nitelikleri taşıyan insanlarla bir araya gelmelerini sağlayan sosyal ağlarda yer aldıkları tespit edilmiştir. Araştırmanın sonuçları, girişimcilerin ortak özellikte olan diğer iş insanları ile yerleşik ilişkiler kurabildiğini göstermektedir. Türkiye'deki yerleşiklik etkisi, Batı'ya göre farklı saikler ve sonuçlar üretmektedir.

Anahtar Kelimeler: Ağlar, sosyal ağlar, örgütler arası ağlar, ağlara katılım nedenleri, yerleşiklik.

JEL Kodları: M10, M12, M14. 


\section{Giriş}

Literatürde örgütlerin, ağ düzenekleri kurarak veya mevcut ağlara dahil olarak, ağ içerisinde yer almayan örgütlere göre kaynak ve bilgiye daha rahat ulaşabilecekleri öne sürülmektedir. Burt (1992), Coleman (1988), Granovetter (1973, 1985), Gulati ve Gargiulo (1999) tarafından ortaya konan farklı çalışmalarda araştırmacılar örgütler arası ağ ilişkilerine önemli katkılar sağlamışlardır. Granovetter (1985) ve Burt (1992) gibi pek çok araştırmacı, sosyal ilişkilerin ekonomik eylemler üzerindeki etkilerine ve ekonomik ve sosyal ilişkilerin örgütler arası ilişkiler üzerindeki etkilerini ve önemini ele almışlardır.

Girişimcilerin sahip oldukları kişisel ilişkilerin işletmeleri için kazanılmış en geçerli ilişki biçimi olacağı varsayımından hareket edilerek, örgütsel ağlara sahip olunmamasının veya mevcut ağların da stratejik olarak yönetilmemesinin olumsuz etkilerinin olacağı öngörülmüştür. Ancak girişimcilerin sosyal ağlara katılım gerekçelerinin sadece stratejik avantaj yaratmak ve örgütsel performansı olumlu etkileyecek kaynaklara ulaşmaktan ibaret olup olmadığı da bir diğer tartışma konusudur. Bir diğer deyimle, işletmelerin, dolayısıyla girişimci ve üst düzey yöneticilerin içinde bulundukları sosyal bağlamın, sosyal ağlara katılım gerekçelerini de değiştirip değiştirmeyeceği, henüz cevaplanmış bir soru değildir. Sosyal yerleşikliğin, örneğin meşruiyet elde etmek, politik gelişmelerden haberdar olmak, politik güç elde etmek gibi doğrudan kaynak erişimi niteliğinde olmayan ikincil amaçları gündeme getirmesi beklenebilir. Hatta, içinde yaşanan toplumun normları, örneğin bir iş insanının belirli sivil toplum kuruluşlarına, derneklere, "üye olması gerektiği" biçiminde kabul edilen davranış esasları, ilgili ağda olmaktan hiçbir stratejik çıkarı olmayan bir girişimciyi orada tutabilmektedir. Yine içinde bulunulan politik ortamın, iş insanlarını belirli sosyal ağların içinde bulunmaya "zorlayabileceğini" düşünmek mümkündür. Türkiye de sosyal, iktisadi ve politik geçmişi ve kurumları ile sosyal ağ kuramının geliştirildiği Anglo Sakson gelenekten önemli ölçüde farklılaşan bir ülkedir. Dolayısıyla girişimcilerin sahip oldukları sosyal ağların niteliğinin ve bu ağlara katılım gerekçelerinin farklılaşabileceğini beklemek mümkün görünmektedir.

Bu çerçevede tasarlanan araştırmanın temel amacı, ağların stratejik önemi konusundaki literatürdeki tartışmaların ortaya konması, Türkiye'deki büyük ölçekli işletmelerin girişimcilerinin sosyal ağlara dahil olma gerekçelerinin tespit edilmesidir. Bu doğrultuda, sosyal ağ kuramına bağlamsal perspektiften bir katkı sunmak amaçlanmaktadır.

Örgütler diğer örgütlerle sürekli etkileşim içindedirler. Örgütler ortaklarıyla, müşterileriyle, tedarikçileriyle ve rakipleriyle karmaşık bir ağ ilişkisi içerisinde yer alırlar. Literatürde ağ düzenekleri içerisine yerleşik örgütlerin, bu sisteme dahil olmayan örgütlerin sahip olamayacağı kaynak ve bilgilere ulaşabileceği öne sürülmektedir. Örgüt teorisi literatüründe, ne tür örgütler arası ağların mevcut olduğu ve örgütlerin bu ağlara katılma nedenleri tartışılagelmiştir. Türkiye'de faaliyet gösteren "isO ilk 500 Büyük Sanayi Kuruluşu" listesinde yer alan işletmelerin yönetim kurulu üyelerinin ağ düzeneklerine girme nedenleri temel araştırma konumuzdur.

Bu çalışmada, işletmelerin bir ağ içinde olmalarının kaynaklara ulaşmak, rekabetçi avantaj elde etmek, inovasyon ve kalite geliştirme gibi konulardaki literatürdeki tartışmaların ve bu ağlara katılma nedenlerinin ortaya konması hedeflenmektedir. Bu amaçla yapılan araştırmalarda, bu ağlara katılma nedenlerinin tespitine yönelik anket uygulaması sonuçları ortaya konulmuştur.

Ağların yapıları ve oluşma nedenleri vardır ve bu ağlara katılma ve ayrılmanın da bir takım sonuçları olduğu görülmektedir. Araştırma yöntemi olarak araştırma verilerine dayanılarak nicel araştırma yöntemleri kullanılmıştır. Belirli bir sorunun veya olgunun doğasını anlamaya yönelik keşfedici bir araştırma ile içerik analizi, gözlem ve anket yöntemleri birlikte kullanılmıştır. Dolayısıyla araştırmamızda tümdengelime dayalı tanımlayıcı bir çalışma yürütülmüştür. Ulaşılan tartışma ve sonuçlarla örgütler arası ağ alanında örgütlerin mevcut durumlarına ayna tutmak ve aynı zamanda ilgili alan yazınına Türkiye bağlamındaki iş insanlarının bu ağlara katılma nedenlerinin tespit edilmesi itibarıyla anlamlı bir katkı sunmak amaçlanmaktadır.

İşletmelerin ağlara katılmaları ve bir ağ içerisinde yer almaları kaynaklara (tedarikçilere, müşterilere, iyi insan kaynaklarına) ulaşma, yenilik ve kalite geliştirme konularında stratejik bir rekabet avantaj sağlıyor mu? Girişimciler neden bu ağlara katılırlar? Bu tartışma ve araştırma sorularının yanıtları, literatürdeki mevcut tartışmalar ortaya konularak ve Türkiye'deki büyük ölçekli işletmelerin iş insanlarının katıldıkları mevcut sosyal ağlara katılma nedenlerine yönelik araştırmalar incelenerek açıklanmıştır.

Araştırma bulguları, Türk girişimcilerin sahip oldukları ağlara katılım nedenlerinin kendine özgü olduğunu ortaya çıkarmakta ve uluslararası literatürdeki bağlamdan farklılık gösterdiğine işaret etmektedir. Bulgulardan anlaşıldığı üzere, girişimcilerin Türkiye bağlamında yerleşiklik ilişkilerine sahip olması, bu durumun temel sebebi olarak görünmektedir. Bu kapsamda araştırmanın bulguları, girişimcilerin bulundukları bu ağlara katılma nedenlerinin yerleşik oldukları bağlamla ilişkili olduğu, bu bağlamdan bağımsız uygulanmasının ve araştırılmasının eksik bir anlayışa sebep olacağı düşüncesini destekler yöndedir. Araştırmamızda, sosyal ağların ekonomik eylemleri nasıl etkilediği yerleşiklik iddiası ile desteklenmiş ve beklenildiği gibi literatürdeki sosyal yerleşikliğin Türkiye'deki durumu açıkladığı tespit edilmiştir.

\section{LITERATÜR TARAMASI}

Örgütler varlıklarını sürdürebilmeleri, başarılı olabilmeleri ve gerekli kaynakları elde edebilmeleri için diğer örgütlerle olan ilişkilerini iyi yönetebilmeleri gerekir (Mizruchi ve Mina, 2002: 599). Provan ve Milward (2001), örgütler için ağa katılımın önemini 
dört ana kriter üzerinde değerlendirmiştir; müşteri sonuçları, meşruiyet, kaynak edinimi ve maliyet (Provan ve Milward, 2001: 420). Kapucu ve Montgomery (2006)'a göre ağlar aracılığı ile örgütler, hiyerarşilerin kolayca başaramadığı kombine kaynak ve uzmanlık gereken özel hedeflere ulaşmak için birbiriyle hızlı ve etkili bir şekilde çalışabilirler (Provan ve Kenis, 2007: 244-245). Örgütler nitelikli insan kaynağına, en iyi tedarikçilere, daha çok müşterilere ve bilgilere daha kolay ulaşmak ve her türlü maliyetlerini azaltmak için stratejik işbirlikleri içerisine girmeyi tercih edebilmektedirler (Borch ve Arthur, 1995: 423-424).

Literatürde ağlarda örgütsel performansı artırmak için iki ana yöntem önerilmektedir; sosyal ağların bilgi, kaynak ve fırsatlara ulaşımda kolaylıklar sağlayabilmesi ve örgütün bağımlıı̆ını koordine etmek ve işbirliği ikilemleri aşmak için aktörlere yardımcı olabilmesidir (Bae ve Gargiulo, 2003: 2). Varsayımlara göre, örgütler için en önemli şey hayatta kalmaktır. Hayatta kalabilmek için örgütler, özelliklede tek başına üretemediği şeylere, kaynaklara ihtiyacı vardır. Dolayısıyla bağlı oldukları çevrede, diğer örgütlerle etkileşimde bulunmaları gerekir. Bununla birlikte, örgütsel hayatta kalma, örgütün diğer örgütlerle ilişkisini kontrol etme kapasitesine dayanmaktadır. Bu nedenle ikili ağ ilişkilerinde (Anderson ve Narus, 1991; Dyer ve Singh, 1998) başarılı olabilmeleri için stratejik ittifaklar (Anand ve Khanna, 2000; Kale vd., 2002) ve endüstri ağları (An vd., 2015; Gulati ve Gargiulo, 1997) gibi yeteneklerini geliştirmişlerdir (Dong vd., 2018: 168). Hakansson gibi bazı araştırmacılarda çevre ve örgüt arasındaki ilişki ile ilgili olarak karşılıklı bağımlılık ve etkileşim sürecini vurgulamışlardır (Mandjak vd., 2011: 823).

Girişimcilik, bağlamında yerleşik olan sosyal bir süreçtir (Sousa vd., 2008: 231) ve iş insanlarının ağları işletmeleri için önemli bir kaynaktır. İş ve kişisel çevreleriyle iyi ilişkileri bulunan iş insanları, ağlarından destek, bilgi, tavsiye gibi önemli faydalar elde edebilmektedirler (Robinson, 2011: 182). Ekonomik eylemin sosyal yapıya yerleşik olduğu fikri, sosyal ilişkilerin ekonomik davranış üzerindeki olumlu ve olumsuz etkileri konusundaki tartışmaları da beraberinde getirmiştir. Çoğu örgüt kuramcısı, sosyal yapının ekonomik davranışta önemli bir rol oynadığını savunurken, birçok iktisat kuramcısı da sosyal ilişkilerin ekonomik işlemleri minimum düzeyde etkilediğini veya Peterson ve Rajan (1994) gibi bazı araştırmacılar da işlemi piyasadan koruyarak verimsizlikler yarattığını iddia etmişlerdir (Uzzi, 1997: 35).

\section{1. Örgütler Arası Sosyal Ağlara Katılma Nedenleri}

Yapılan çalışmalarda, örgütlerin ve girişimcilerin yeni bir şeyler söyleyebilmek, değer platformlarını geliştirebilmek, ağ içinde öğrenme, yenilikçiliğe katkı sağlamak ve rekabet gücünü artırabilmek gibi çeşitli nedenlerle ağlara katılmaktadırlar. Alter ve Hage (1993), Edelenbos ve Klijn (2007) ve Uzzi (1997) tarafından ortaya konan farklı çalışmalardaki ağlarla ilgili literatürdeki ortak tema, işbirliği yoluyla güven oluşturmaya ağ etkinliği açısından kritik öneme sahip olacaktır (Provan ve Kenis, 2007: 242).

Bazı araştırmacıların çalışmalarında, girişimcilerin ve yeni işletmelerin hayatta kalmak için ağlara girmeleri gerektiği iddia edilmektedir (Huggins, 2000: 112). Szarka (1990), Brüderl ve Preisendörfer (1998) tarafından ortaya konan çalışmalarda araştırmacılar girişimcilerin ağ kurması gerektiğini iddia ederlerken, Arocena (1984) gibi diğer araştırmacılar ise yeni işletmelerin başarısı ya da başarısızığının kurucuları tarafından geliştirilen ağlara bağıı olduğu öne sürmektedir (Dodd, Jack ve Anderson, 2002: 213). Literatürde ağ kurmanın güç ve politikaya odaklanma ve fırsat yaratma konusunda bir strateji olduğunu öne süren araştırmalar da bulunmaktadır (Wolf ve Kim, 2012: 45).

Örgütler kendi kendine yeterli olmadıklarından, hayatta kalmak için ihtiyaç duydukları kaynakları ve bilgileri elde etmek için çevreyle değişime girmelidirler. Örgütlerin bilgi ihtiyacı belirsizlik (Thompson, 1967), kaynak ihtiyacı (Pfeffer ve Salancik, 1978) bağımlılık yaratır (Baum ve Rowley, 2002: 8). Örgütler, meşruiyet kazanma, müşterilere daha etkili hizmet etme, daha fazla kaynak çekme ve karmaşık sorunları ele alma gibi çeşitli nedenlerle ağlara katılırlar (Provan ve Kenis, 2007: 240).

Ağ işletmeleri, ağlara girmek veya kurmak için çok sayıda motife sahip olabilirler. Hutt ve Speh (1995)'e göre bir işletmenin kendi dağıtım kanallarını, lojistik ağını, üretim tesisini ve araştırma geliştirme işlevini oluşturmasında her zaman bir maliyet ve risk vardır (Hinterhuber ve Hirsch, 1998: 187). Dyer ve Singh (1998)'e göre işletmeler arası ilişkiler, işletmelerin kritik kaynaklara ulaşmalarına ve rekabetçi avantajlar yaratmalarına olanak sağlar (Demirkan ve Deeds, 2007: 1).

Ağlar, çoğu durumda işletmelerin gerekli olan dış kaynaklara erişmek için kullandıkları yöntemdir (Jarrillo, 1988: 39). Genel olarak örgütler teknolojik kabiliyetler de dahil olmak üzere faktör piyasalarında bulunmayan kritik kaynakların elde edilmesi (Hagedoorn, 1993), yüksek girişim engelleri olan piyasalara erişim (Baum vd., 2000) ve meşruiyet (Baum ve Oliver, 1991) için stratejik bir faktör olmaktadır (Bae ve Gargiulo, 2003: 3).

Örgütler kiritik kaynaklara erişmek için birbirleriyle ittifaklar kurarlar ancak işbirliği yapacak kişileri belirlemek için önceki ittifak ağından gelen bilgilere dayanırlar (Gulati ve Gargiulo, 1999: 1439). Park'a (1996) göre ağ ilişkileri sayesinde ilgili bilgiye ve kaynaklara sahip olmak; piyasa sistemine ve içsel büyümeye göre daha kolay, daha hızlı ve daha az masraflı olacaktır (Park, 1996: 804). 
Araştırmalar, örgütlerin ortak çevrede birbirine bağımlılık getirdiği problemlere yanıt olarak diğer örgütlerle bağlara girdiğini göstermektedir. Örgütler hedeflerini gerçekleştirmek için gerekli olan, en azından kısmen kendi çevrelerindeki diğer örgütlerin kontrolü altında olan yeteneklere ve kaynaklara erişmek için işbirliği bağları kurarlar (Gulati ve Gargiulo, 1999: 1443).

Önceden yapılan araştırmalarla tutarlı olarak örgütler tamamlayıcı kaynaklara ve yeteneklere sahip olan diğer örgütlerle bağlar kurarlar. Gulati ve Gargiulo (1999)'nın yapmış oldukları araştırma sonuçları, hem karşılıklı bağımlılığın hemde ağ yerleşikliğinin yeni ittifaklar oluşumuna önemli etkisi olduğunu göstermiştir (Gulati ve Gargiulo, 1999: 1476).

Potansiyel ağ üyeleri bir ağa girmek veya kurmak için şu nedenlerden bir veya birkaçına sahip olacaktır (Hinterhuber ve Hirsch, 1998: 187); yabancı pazarlara girmek, risk azaltma, risk ekonomileri, rasyonellik ve sinerji, pazar payının artırılması, teknoloji ve patentlere erişim, bilgilerin toplanması, seçme ve engelleme yarışması, moda ve kurumsal etkiler.

İşletmeler geliştirmiş oldukları ilişkiler ve ağ bağlantıları sayesinde, kısa bir süre içerisinde uluslararası pazarlara açılabilmektedirler. Ağlar dış pazarlara erişim sağlayabilir ve köprüler kurabilirler. Bir işletmenin uluslararasılaşma niyetini desteklemek için harekete geçme olasılığı, bir ağa katılımın temel nedenidir. Bir ağ, iş ortağının mevcut deneyiminden yararlanarak, uluslarası pazarlara girmek isteyen işletmeler için muazzam bir destek olacaktır. Axelsson ve Easton (1992)'e göre işletmelerin uluslararasılaşması, dış pazarlarda ağ pozisyonları oluşturması ve geliştirmesi anlamına gelir (Hinterhuber ve Hirsch, 1998: 187).

Granovetter ve Polanyi tarafından ortaya konan çalışmalarda araştırmacılar, yerelliğin ağların yapısını da bu ağlara katılma nedenlerini de etkilediğini ve her yerde aynı gerekçelerin olmayacağını vurgulamışlardır. Dolayısıyla Türkiye bağlamında girişimcilerin ağ ilişkilerinin de ağa katılım gerekçelerinin de bağlama göre değişeceği ve bu nedenle Amerikan bağlamından farklılık gösterebileceği beklenilmektedir.

\subsection{Bağlam Kapsamında Türkiye'de Örgütler Arası Ağ iliş̧ileri}

Makro kuramsal yaklaşıma göre, her ülkedeki ekonomik etkinliklerin örgütlenme biçimi o ülkenin tarihsel, siyasal, ekonomik ve kültürel özelliklerini yansıtacak biçimde kendine özgüdür. Makro kurumsal yaklaşımlar içerisindeki Biggart ve Hamilton'in (1991) otorite yaklaşımı ve Whitley (2000) ulusal iş sistemi yaklaşımları, ulusal bazdaki kurumsal bağlamın oluşumunda devletin rolünü vurgulamışlardır. Türkiye'de örgütler arası ilişkilerin mevcut durumu, Granovetter'in (1978) ve Coleman (1988)'ın, Burt (1992) ve Podolny (2001) yerleşiklik tartışmaları çerçevesinde, ekonomiyi yönlendiren dinamiklerin açıklanmasına yardımcı olabileceği düşünülmektedir. Kaynak bağımlılığı (Pfeffer ve Salancik, 1978), örgütler arası ağ (Baker ve Faulkner, 2002) ve makro kurumsalcı (Whitley, 2000) yaklaşımlardan yararlanılarak geliştirilen kuramsal çerçevede, bir sektördeki örgütlerin farklı diğer örgütlerle ilişkilerinin yönü (yatay-dikey) ve niteliğinin yerleşik ilişkilerinin o sektörün devlete bağımlılık derecesine ve sektördeki örgütlerin farklı sosyo ekonomik grupları temsil etme derecesine bağlı olduğunu öngörmektedir (Sargut vd., 2007: 1-2).

Türkiye'de örgütler arası ilişkilerin mevcut durumu, devlete bağımlılığın ağ ilişkileri üzerindeki etkisini vurgulayan Whitley'in (2000: 858) ulusal iş sistemleri yaklaşımı ve Granovetter'in (1978) ve Coleman'ın (1988), Burt (1992: 229) ve Podolny (2001) yerleşiklik tartışmaları çerçevesinde ele alındığında, ülke ekonomisi yönlendiren dinamiklerin açıklanmasına yardımcı olabilecek bir model üretilebilmektedir. Araştırmamızda örgütlerin ağ ilişkilerinin yönünü belirleyebilecek, devletin piyasalarda üstlendiği role vurgu yapan Whitley'in ulusal iş sistemleri yaklaşımından faydalanılmıştır (Sargut vd., 2007: 27-28). Türkiye'de devlet, girişimci sınıfın yaratılması sürecinde kritik bir rol oynamıştır (Öniş ve Şenses, 2007: 4). Geçmişten günümüze uzun vadeli krediler, sübvansiyonlar, teşvikler ve vergiden muafiyet gibi araçlarla kamu desteğine bağımlı bir girişimci sınıfı yaratılmıştır (Heper, 2015: 174). İş insanlarının siyasetçilerle uzun vadeli krediler, teşvikler ve muafiyetler gibi çeşitli faydalar elde etmek için yakın ilişkiler geliştirdikleri gözlenmektedir (Buğra, 1995: 97).

Burt ve Lin (2001), sosyal sermayeyi ağ yoluyla aktörlere sağlanan bir kaynak olarak yorumlamışlardır. Sosyal sermaye, ağ aracılığıyla fayda sağlamak beklentisi ile aktörlerin ilişkilerine bir yatırım olarak görülmektedir (Lin, 2001: 19-25). Güçlü bağlara sahip olmak iş insanları için güven ve itibar kaynağı olabilmektedir (Gulati, 1995: 623). Türkiye bağlamında siyasetçilerle güçlü bağlar geliştirmek, iş insanlarının işletmeleri için ihtiyaçları olan güven ortamının oluşmasına ve istedikleri yönde etki etme gücü sağlayabilir. Örgütler meşruiyet kazanabilmek için, içinde bulundukları sosyal sistem içerisinde kabul edilebilir davranış normları ile örgütsel faaliyetleri arasında bir uyum sağlamaya çalışırlar (Dowling ve Pfeffer, 1975: 122). Mardin'e (2003) göre yerleşiklik, merkez ile çevre arasındaki çatışmayı doğuran bir alandır (Mardin, 2003: 137).

Türkiye'de işletmelerin yönetim kurullarının mülkiyet yapılarının, genellikle eş, dost ve akrabalardan oluştuğunu görülmektedir (Arıkboğa ve Menteş, 2009). Özsoy (2011), iMKB'de işlem gören halka açık işletmelerin yönetim kurullarının işleyişi hakkında, 2005 yılında 155 firma ve 256 yönetim kurulu üyesi üzerinde görgül bir araştırma yapmıştır. Araştırma sonucunda, Türkiye'de sermayenin belirli ellerde toplandığı ve bu yapı içinde ailelerin pay sahipleri arasında baskın olduğunu tespit etmiştir. Paşa, Kabasakal ve Bodur (2001)'a göre de Türkiye' de iş yaşamında, aile üyeleri tarafından yürütülen özel işletmeler baskın konumdadır. Kabasakal ve Bodur (2002), Globe araştırması sonucunda, Türk toplumunda özellikle aile işletmelerinde önemli pozisyonlarda 
bulunan kişilerin aile üyelerinden, akrabalarından, tanıdıklarından veya aynı okuldan mezun olunan arkadaşlardan oluştuğunu ileri sürmüşlerdir (Tunçay ve Özer, 2017: 487-488).

Koç (1983) hatıralarında, sivil toplum kuruluşlarıyla iletişim kurmak için ilişkilerden nasıl faydalandığını anlatmaktadır. Sabancı (1985) hatıralarında, odalar birliği yönetim kurulu üyesi olduğu sırada, bu konumunun sağladığı avantajla, Koç'un yabancı bir ortakla aynı malı üretmek için izin almasını engellediğini anlatmıştır (Buğra, 2008: 126). Sabancı'nın sahip olduğu avantajlı konumunu koruduğu görülmektedir. Baysal'ın hayat hikayesinde, kendi ürününe ait, kural koyucunun çıkarmış olduğu bir engeli, uluslararası bir kuruluşa üye olarak bu engeli aşmaya çalıştığından bahsedilmiştir (Çitçi ve Coşkun, 2012: 149-150).

Belirli bir sektördeki örgütler arası ilişkilerin, o sektördeki örgütlerin yerleşik olduğu sosyo ekonomik ilişkiler ağından etkilenmesi söz konusudur. Mardin (1973) ve Heper (1985)'e göre Türk iş sisteminin toplumsal yapıyı yansıtan belki de en belirgin özelliği merkez-çevre ikiliğidir. Mardin (1973)'in dediği gibi her zaman toplumun bir merkezi vardır. İs sisteminin merkezinde görece yaşlı, büyük, uluslararasılaşma derecesi yüksek TÜSiAD çerçevesinde örgütlenmiş holding şirketleri yer alırken çevrede ise görece küçük, genç merkezleri Anadolu da yer alan MUSiAD ile TOBB çevresinde örgütlenmiş holding ya da bağımsız işletmeler yer almaktadır (Sargut vd., 2007: 28).

Buğra (1994), Buğra ve Üsdiken (1995), Öniş (1995) Türkiye'deki büyük işletme organizasyonunun baskın şekilde genellikle aile işletmeleri biçimindeki işletme grupları olarak tanımlamışlardır (Gökşen ve Üsdiken, 2001: 326). Türkiye'de hukuki ve yasal düzenlemelerin ve ülkenin sahip olduğu organların, örgütlerin yaşamlarını sürdürmeleri açısından önemli değişkenler olduğu kabul edilir (Yeloğlu, 2005: 14).

Türkiye'de aktörlerin sosyal sermaye oluşturma eğilimi konusunda toplumun güven algısı ve kültürel özelliklerinin örgütlenme biçimlerine olan etkisine dair bazı araştırmalarda ülke ekonomisindeki aktörlerin ağ ilişkilerinin oluşumunda belki de en önemli unsurlardan biri olan devletin Türkiye'nin kuruluşundan itibaren üstlendiği role dikkat çekilmiştir (Buğra, 1994: 227-228). Devletin rolü, örgütsel ağ ilişkileri bağlamında gelişen piyasa ilişkisi, yerleşik ilişki tartışmalarına farklı bir boyut kazandırmıştır. Siyasetçiler ve bürokratlarla kurulacak yakın bağların önemine ve devletin ekonomideki baskın rolüne dikkat çekilmiştir (Sargut vd., 2007: 1516). Türkiye' de özel sektör, TÜsiAD gibi sivil toplum kuruluşları aracılığıyla, devlet ile sürekli bir diyalog içerisinde bulunarak güçlü bağlar geliştirmişlerdir (Bikmen ve Meydanoğlu, 2006: 75). TÜsiAD’ın “Türk Toplumunun Değerleri” araştırmasında, Türk toplumunun özellikleri arasında "yakın çevre dışındakilere güvensizlik" ve "rekabetten kaçınma" özellikleri dikkat çekmektedir (TÜSIAD, 1991: 11).

T.C. İç İşleri Bakanlığı verilerine göre 2020 yıl sonu itibariyle Türkiye'de121.527 faal dernek bulunmaktadır ve bu derneklerin faaliyet alanlarına göre \%31,54'ü (38.326) mesleki ve dayanışma derneğidir (siviltoplum.gov.tr/derneklerin-faaliyet-alanlarınagore-dagılımı). 2020 yıl sonu itibariyle Türkiye genelinde 16.829 hemşehri derneği bulunmaktadır ve bunun \%53,49’u Marmara bölgesinde (9.001), \%21,78'i iç Anadolu bölgesinde (3.665), \%8,47'si Karadeniz bölgesinde (1,425) ve \%7,14'i de Ege bölgesinde $(1,201)$ yer almaktadır (siviltoplum.gov.tr/hemsehri-derneklerinin-bolgelere-gore-dağilimi).

Buğra (2001), Sargut (2003: 115), Gökalp (2003: 173), Karagül ve Masca (2005: 48) gibi araştırmacıların sosyal sermaye konusunda yaptıkları çalışmalarda Türk toplumu sosyal sermayesi zayıf bir toplum olarak tanımlanmıştır. Bu sonuç, Türkiye'de insanların tanımadığı kişilere güven düzeyinin diğer toplumlara göre düşük çıkmasına dayandırılmaktadır. Türk toplumunun toplulukçuluk, belirsizlikten kaçınma ve güç mesafesi gibi baskın değerleri (Sargut, 2003: 108) nedeniyle, yabancının yabacıya güvenmesini sağlayacak bir ortamın oluşamadığı ve insanların sadece akrabalık, hemşehrilik gibi birincil bağlarla bağlı olduğu kişilere güvendikleri öne sürülmektedir (Özen ve Aslan, 2006: 131). Belki de benzerlik ilkesinin en temel kaynağı coğrafi konumdur ve bize daha yakın olanlarla uzak olanlara göre daha fazla temasımız vardır (McPherson vd. 2001: 429). Bu Türk toplumundaki işlerin yürütülmesindeki toplulukçu kültürel değerler yaklaşımı nedeniyle kişisel ilişkilerinde ön plana çıktığı iddia edilmektedir (Sargut, 2003: 103).

Bu çalışmada esas alınan soru, girişimcilerin hangi sosyal ağlara katıldıklarının, bu konudaki seçimi hangi kriterlere göre yaptıklarının ve sosyal ağlardan beklenti ya da kazanımlarının bağlamsal değişkenlik gösterip göstermediğidir. Girişimcilerin, farklı kültürel ve kurumsal bağlamlarda farklı aktörlerle sosyal ağlar oluşturmaları beklenebilir. Örneğin hemşehrilik bağı, Türkiye'ye özgü bir sosyal ilişki biçimidir. Benzer biçimde dini inançlar ve topluluklar da hem kültürel hem ekonomik temelde birçok sosyal bağlantıya temel oluşturabilmektedir. Bu nedenle söz konuşu araştırma, Türk iş insanlarının sosyal ağ özelliklerini ve bu ağlara dahil olma nedenlerini tespit etmeye yönelmektedir.

\section{AĞLARA KATILMA NEDENLERINE ILIŞKIN GEREKÇE VE BEKLENTiLERIMiz}

Amerikan iş insanları çok daha rekabetçi gerekçeler ile ağlara katılmaları beklenilirken Türk iş insanlarının yerel olarak bağlama göre ağlara katılma nedenlerinin değişmesi beklenmektedir. Granovetter ve Polanyi tarafından tartışılan yerleşiklik olgusunun Türkiye'de özgün bir ağ oluşumlarını ve ağlara katılma nedenlerini gündeme getirebileceğini söylemek mümkün görünmektedir. Türkiye gibi gelişmekte olan, piyasanın ciddi bir biçimde devlet tarafından etkilendiği bir ülkede, Türkiye bağlamında ve Türk iş 
insanları özelindeki durum, net bir biçimde belirlenmiş değildir. Bu açıdan, sosyal ağlara katılım nedenlerinin bağlamsallığına ilişkin olarak Türkiye'ye özgü biçimde elde edilecek bulguların sosyal ağ kuramına bir katkı sağlaması beklenmektedir.

Gulati'ye göre kaynaklara erişim ve stratejik avantaj devşirme arayışı ağların varlık nedeni ve aynı zamanda ağa katılım sebebi olarak görülmektedir. Ancak piyasanın ciddi biçimde devlet tarafından etkilendiği bir bağlamda aynı sonuç elde edilemeyebileceği gözlemimiz araştırmamızda girişimcilerin ağlara katılma nedenleri literatürden geliştirilen gerekçeler ile sınanmıştır.

Sosyal ağlar, girişimcilerin güvenilir insanlarla iletişim kurmalarına yardımcı olmaktadır. Güven inşa etmek için hayır kurumları, spor kulüpleri ve hobi kulüplerine üye olmak yararlı ağ türleri olarak görülmektedir (Casson ve Giusta, 2007: 231). Bu çalışmada, girişimcilerin ve yöneticilerin formel ve enformel ağlarının ve sosyal sermayelerinin öneminin bilinciyle davranarak sosyal ağ düzeylerini artırmak için harekete geçecekleri ve girişimcilerin güven düzeylerinin yükselmesi için neler yapılabileceğinin değerlendirileceğine, girişimciler açısından, hem işletmenin kurulması hem de devam ettirilmesi aşamalarında, finansal sermayenin yanında formel ve enformel ağlarının da ve sosyal sermayenin de önemli olabileceğinin farkına varılmasının önemi açıklanmaktadır.

Farklı bir makro ve siyasi konjonktüre sahip olan gelişmekte olan bir ülke olarak Türk girişimcisinin ağ kullanma biçimlerinin hangi nedenlerle açıklanabilineceğinin ortaya konması hedeflenmektedir. Bu amaçla geliştirilen 10 gerekçenin sınanması ve elde edilen bulguların karşılaştırılması ve yorumlanması sağlanacaktır. Bu çalışmada ulusal ve uluslararası literatür taraması çerçevesinde bazı gerekçeler ileri sürülecek ve araştırmamızda girişimcilerin sahip olmuş oldukları sosyal ağlar çerçevesinde tartışılması ve tespit edilen bulguların yorumlanması sağlanacaktır. Gerekçelerimizde yer alan sosyal ağlar hem formel (biçimsel) hem de enformel (biçimsel olmayan) sosyal ağları ifade etmektedir.

Baum ve Oliver (1991: 193)'a göre, örgütler arası ağ ilişkileri, meşruiyet kazanmanında bir yolu olarak görülmektedir. Sydow ve Windeler (1998: 269)'e göre ağlar, daha fazla meşruiyet gibi gelişmiş stratejik hedefler peşinde koşmaktadırlar. Nelson (1988: 3958)'e göre sosyal ağlar meşruiyet kazanmada önemli bir rol oynarlar. Dowling ve Pfeffer (1975: 122)'e göre örgütler meşruiyet kazanabilmek için, içinde bulundukları sosyal sistem içerisinde kabul edilebilir davranış normları ile örgütsel faaliyetleri arasında bir uyum sağlamaya çalışırlar. Literatürdeki bu tartışmalara istinaden araştırmada iş insanlarının sosyal ağlara katılım gerekçelerinden ilki "girişimcilerin saygınlık ve toplumsal olarak kabul görmek, tanınırlık ve bilinirlik elde etmek için sosyal ağlara katıldıkları” yönündedir. Beklentimiz, girişimcilerin meşruiyet elde etmek için formel ve informel (sosyal) dernek, oda, birlik, çeşitli sivil toplum kuruluşlarına, federasyon ve birliklerine üye olmalarıdır.

Kenis ve Oerlemans (2007: 302)'e göre örgütler ağ düzeneklerine dahil olduklarında çok çeşitli kaynaklara ulaşıp paylaşabilmektedirler. Jarillo (1988: 39)'a göre ağlar, çoğu durumda işletmelerin gerekli olan dış kaynaklara erişmek için kullandıkları yöntemdir. Baum ve Oliver (1991: 193)'e göre örgütler arası ağ ilişkileri, kaynaklara erişimin bir yolu olarak görülmektedir. Kaynak tabanlı görüşe göre stratejik ağlar, işletmelerin kilit kaynaklara (Eisenhardt ve Schoonhoven, 1996) erişmelerine yardımcı olabilir (Xie ve Gao, 2018: 821). Özellikle stratejik ağlar, kaynaklara erişim gibi avantajlar sağlar (Gulati vd., 2000: 203).

Gargiulo ve Benassi (2000: 184)'e göre sosyal ağlar kaynaklara ve fırsatlara erişimi kolaylaştırabilir. Girişimcilerin nitelikli ve hızlı bir şekilde insan kaynağına ulaşabilmeleri, daha kolay sermayeye erişebilmeleri, maddi destek görebilmeleri, kriz dönemlerinde krizleri daha kolay atlatabilmeleri ve finansal kuruluşlardan daha kolay sermaye edinimi sağlayabilmeleri ve sosyal dayanışma için sosyal ağlara katıldıkları iddia edilmektedir. Beklentimiz, iş insanlarının en uygun insan kaynağına, teknolojiye, bilgiye, yeniliklere ve benzeri kaynaklara ulaşabilmek için sosyal ağlara üye olmalarıdır. Literatürdeki bu tartışmalara dayalı olarak araştırmada öne sürülen 2. sosyal ağlara katılım gerekçesi, "iş insanlarının çeşitli kaynaklara ve bilgiye ulaşmak amacıyla sosyal ağlara dahil olduğu” yönündedir.

Thorelli (1986: 46)'e göre ağlar yeni müşterilere ulaşmak için bir araç olarak görülebilir. Provan ve Milward (2001: 420)'e göre örgütler için ağa katılım yeni müşteri edinimini sağlayabilir. Adler ve Kwon (2002:17)'e göre ağlar müşterilere ulaşma gibi konularda avantajlar sağladığı iddia edilmektedir. Beklentimiz, girişimcilerin müşteri hizmetlerinin paylaşımı veya değişimi, müşterilerin tüm gereksinimlerini karşılamada iş birliği, müşterilerine daha etkili hizmet etmek, yeni müşterilere ulaşabilmek için bir araç ve müşterilerine daha etkili hizmet için sosyal ağlara üye olmalarıdır. Literatürdeki bu tartışmalara istinaden araştırmada öne sürülen 3. sosyal ağa katılım gerekçesi "girişimcilerin yeni pazarlara ve müşterilere ulaşmak için sosyal ağlara katıldıkları" yönündedir.

Jarillo (1988: 35)’e göre ağ, bir maliyet disiplini sunar. Gray ve Wood (1991: 3) ağ oluşturma için bir gerekçe olarak verimlilik ve işlem maliyetlerinde azalma öngörmektedir. Möller ve Svahn (2003)'e göre stratejik ağ verimliliği, faaliyetlerin ve kaynakların koordinasyonu yoluyla işlem ve/veya operasyonel maliyetlerin azaltılmasını amaçlamaktadır. Sydow ve Windeler (1998: 269)'e göre stratejik ağlar, özellikle işlem ve üretim maliyetlerini düşürmek suretiyle çeşitli gelişmiş stratejik hedefler peşinde koşmalarını sağlarlar. Gulati vd. (2000: 209)'e göre sosyal ağlar güveni artırır ve işlem maliyetlerini birkaç şekilde azaltır. Bu çerçevede araştırma kapsamında öne sürülen 4. gerekçe, "girişimcilerin hammadde malzeme tedariki konusunda etkinlik sağlayabilmek için 
sosyal ağlara katıldıkları” biçimindedir. Beklentimiz, girişimcilerin çeşitli dayanışma dernek ve birliklerine, ticaret borsalarına, organize sanayi bölgelerine ve iş insanları derneklerine üye olmalarıdır.

Möller ve Halinen (2017: 13) gibi ağların değer yaratma karakterini vurgulayan yazarlar, bir ağın, bir değer platformu inşa ederek, ağın ve üyelerinin rekabet gücünü artıran bir değer sistemi yaratabileceğini öne sürmüşlerdir. Dyer ve Singh (1998)'e göre stratejik olarak değerli ürün ve hizmet tedarikçileriyle ilişkilerin bulunduğu ağları, önemli ve kalıcı bir rekabet avantajı kaynağı olabilir (Ritter vd., 2004: 177). Jarillo (1993), Alter ve Hage (1993) gibi bazı araştırmacılara görede ağlar, rekabet avantajı sağlarlar. Gulati vd. (2000:207)'e göre işletmelerin ağları da sürdürülebilir rekabet avantajı kaynağı olarak hizmet edebilir (Pratono, 2018: 682). Burt (1992)'e göre bir sosyal ağ yapısı içerisindeki aktörlerin bağlantıları ve bu ağdaki konumlar rekabet avantajı sağlayabilmektedir. Bu çerçevede araştırma kapsamında öne sürülen 5. sosyal ağa katılım gerekçesi, "girişimcilerin rekabet avantajı kazanabilmek, rekabette rakiplerine karşı avantajlı konuma geçebilmek için sosyal ağlara katıldıkları" yönündedir. Beklentimiz, girişimcilerin stratejik ve rekabetçi avantajlar sağlayacak işbirlikçi ağlara üye olmalarıdır.

Gargiulo ve Benassi (2000: 183)'e göre ağın görev ortamındaki önemli değişikliklere uyum sağlaması önemlidir. Jones, Hesterly ve Borgatti (1997)'e göre ağ yönetişimi, çevresel koşullara uyum sağlamak ve değişimleri koordine etmelerini sağlar (Jones vd., 1997: 914-915). Literatürde Möller ve Rajala (2007) gibi bazı araştırmacılara göre genel olarak örgütler arası ağların kurulması ve yönetilmesi için uyumun kritik rolü kabul edilmektedir (Perks vd., 2017: 109). Achrol ve Kotler (1999: 147)'e göre ağlar daha esnektir ve daha kolay uyum sağlamaya yardımcı olabilirler. Ibarra ve Hunter (2007)'e göre ağa güç veren ilişkilerin kalitesi, uyum ve karşılıklı güvendir. Chell ve Baines (2000: 195) araştırmaları, iş insanlarının ticari bağlantılarını yararlı ek bilgi kaynakları olarak kullandıklarını göstermiştir. Literatürdeki bu tartışmalara istinaden araştırmada öne sürülen 6. sosyal ağa katılım gerekçesi, "girişimcilerin dış çevreden haberdar olabilmek, pazarlar, piyasalar ve politikalar hakkında bilgi edinebilmek için sosyal ağlara katıldıkları" biçimindedir. Beklentimiz, girişimcilerin çeşitli sivil toplum kuruluş, dernek ve kulüplerine, dayanışma dernek ve birliklerine, kültür, sanat ve turizm vakıflarına üye olmalarıdır.

Dougherty ve Dunne (2011)'e göre stratejik ağlar, bilgi paylaşımını kolaylaştırarak yenilik hızını artıır. Xie ve Gao (2018: 812)'e göre stratejik ağlar, işletmelerin yenilikçiliğini hızlandırmasına ve böylece rekabet avantajı elde etmesine ve böylece yenilik faaliyetlerine ilham vermesine yardımcı olabilir. Öberg, Shih ve Chou (2016)'a göre genel olarak stratejik ağlar, yenilikçiliği iyileştirmede önemli bir rol oynamaktadır. Sydow ve Windeler (1998: 269)'a göre genel olarak stratejik ağlar, örgütler arası öğrenme gibi gelişmiş stratejik hedefler peşinde koşmaktadırlar. Podolny ve Page (1998: 62)'e göre ağlar bir aktörden diğerine bilgi transferi sağlayarak öğrenmeyi etkinleştirir Bu çerçevede, girişimcilerin sosyal ağlara katılımına ilişkin 7. gerekçe, "girişimcilerin sektör, ürünler ve müşteriler ile ilgili yeni gelişmelere, bilgilere, yenilikçi fikirlere ulaşabilmek, takip edebilmek ve öğrenebilmek amacıyla, sektördeki en iyi uygulamaları görmek, tanımak, rakiplerinin veya diğer işletmelerin başarılı neler yaptıklarından, başarılı uygulamalarından haberdar olabilmek için sosyal ağlara katıldıkları" biçimindedir. Beklentimiz, girişimcilerin ağ içinde örgütsel ve bireysel öğrenme araçları ile yenilikçi kaynaklarına ulaşabilmek, yeniliklerin erken farkına varılabilmesi ve yenilikçiliğin hızlandırılmasına, uluslararası ölçekte yenilik yapmasına ve büyümesine olanak sağlaması için sosyal ağlara üye olmalarıdır.

Bu çalışmada ağların, işletme stratejilerinin belirlenmesi üzerindeki belirleyici etkisi olduğu öngörülmekte ve ağların işletmelerin uluslararasılaşma yolunda önemli bir stratejik araç olarak kullanıldığı görüşü desteklenmektedir. Jaklic (1998: 381)'e göre işletmeler uluslararası ağ oluşturma yoluyla, uluslararasılaşma süreçlerini hızlandırma fırsatı elde ederler. İşletmeler geliştirmiş oldukları ağlar sayesinde çok hızlı uluslararasılaşırlar (Hinterhuber ve Hirsch, 1998:187). Jaklic (1998:359) gibi literatürdeki çeşitli araştırmalarda, КОВі'lerin uluslararasılaşmalarında ağ bağlantılarının önemine dikkat çekilmektedir. Literatürdeki bazı çalışmalarda uluslararasılaşmada ağ bağlantılarının önemine vurgu yapıldığı görülmektedir (Johanson ve Vahlne, 2009; Johanson ve Mattsson, 1988). Bu çerçevede tespit edilen 8. gerekçe, "girişimcilerin ihracat veya diğer uluslararası faaliyetlerinde avantaj yaratabilmek için sosyal ağlara katıldıkları" yönündedir. Beklentimiz, girişimcilerin ticaret borsalarına, ihracatçı birliklerine üye olmaları ve ülkelerin fahri konsolosluklarını üstlenmeleridir.

Burt (1992), sosyal sermayenin girişimciye sağladığı güç üzerinde durmuştur. Örgütlerin fiziksel kaynaklara, bilgiye, siyasi gücü elinde bulunduran taraflara ulaşarak hayatlarını devam ettirmelerinde yerleşik ilişkilerin rol oynayabileceği düşünüldüğünde, sahip olunan ilişkilerin sayısı ve gücü de performanslarını etkileyen önemli bir unsur olarak ön plana çıkmaktadır (Rao vd., 2000: 268). Literatürde bir ortaklığın gelişmesinde köprü olarak bir siyasi bağ kullandığından bahsetmektedir. Benson (1975)'e göre örgütler arası ağ, iki kıt kaynağın, paranın ve otoritenin dağıtımıyla ilgili politik bir ekonomi olarak düşünülebilir (Thorelli, 1986: 39). Makro kurumsal yaklaşımlar içerisindeki Biggart ve Hamilton'in (1991) otorite yaklaşımı ve Whitley (2000) ulusal iş sistemi yaklaşımları ulusal bazdaki kurumsal bağlamın oluşumunda devletin rolünü vurgulamaktadır. Literatürdeki bu tartışmalara istinaden araştırmamızın 9. gerekçesinde, "girişimcilerin siyasi destek elde etmek veya siyasi gelişmelerden öncelikli olarak haberdar olabilmek için sosyal ağlara katıldıkları" kabul edilmektedir. Beklentimiz, girişimcilerin siyasi parti ve komisyonlara üye olmaları ve siyasi görevlerde bulunmalarıdır. 
Oliver ve Ebers (1998: 563)'e göre, örgütler çeşitli stratejiler kullanarak, sistem içindeki kendi güçlerini artırmak için bir ağa katılarak çevresel bağımlılıklarını azaltma sürecine odaklanırlar. Gulati ve Gargiulo (1999: 1440)'e göre stratejik ağlar, çevresel belirsizliği yönetmenin bir aracı olabilirler. Perez, Montes ve Morales (2014) 'e göre yüksek derecede çevresel belirsizlik varsa, stratejik esneklik geliştirmek için, güçlü sosyal ağların kullanılması daha fazla teşvik edilebilir. Perez vd., (2014:861)'e göre son derece belirsiz ortamlarda faaliyet gösteren örgütler, dış ortamlardaki değişiklikler hakkında daha iyi tahminler yapmak için sosyal ağlar kurma eğilimindedirler. Literatürdeki bu tartışmalara istinaden araştırmada öne sürülen 10. sosyal ağa katılım gerekçesi, "girişimcilerin belirsizlikleri ve riskleri azaltabilmek, bilgiye daha kolay ulaşabilmek için sosyal ağlara üye oldukları" biçimindedir. Beklentimiz, girişimcilerin çevrenin belirsiz ortamlarını yönetmek ve başa çıkmak için çevresel belirsizliği yönetmenin bir aracı olarak görmeleridir.

Bu çalışmada, farklı bir makro ekonomik ve siyasi arka plana sahip, gelişmekte olan bir ülke olan Türkiye'deki iş insanlarının ağ kullanma biçimlerini anlamak ve hangi nedenlerle, hangi sosyal ağlara dahil olduklarını açıklamak amacından hareket edilmektedir. Literatürdeki tartışmalardan yola çıkarak oluşturulan araştırma sorularını açıklamaya yönelik kuramsal çerçeve geliştirilmiş ve ağlara katılma nedenlerine yönelik gerekçeler oluşturulmuştur. Bu amaçla ulusal ve uluslararası literatür taraması çerçevesinde geliştirilen 10 gerekçenin sınanması, girişimcilerin sahip olmuş oldukları sosyal ağlar çerçevesinde tartışılması, elde edilen bulguların karşılaştırılması ve yorumlanması sağlanacaktır.

Literatürde işletmelerin ve girişimcilerin karar verirlerken stratejik amaçlarının gereklerine göre hareket ettikleri ve sosyal ağlarını bu doğrultuda, bir rekabet avantajı yaratabilmek için kullandıkları savunulmaktadır. Beklentimiz, Türkiye bağlamında iş insanlarının örgütler arası ağlarının ve bu ağlara katılma nedenlerinin ABD ve Avrupa ülkelerine göre farklılık göstermesidir. Türkiye'deki iş insanlarının örgütsel ağları açısından bakıldığında farklı kısıtlar oluşacağı beklenmektedir. Türkiye'ye özgü örgütler arası sosyal ağların ve ağlara katılma nedenlerinin biçimlerinin ortaya çıkması çalışmamızın ana temalarını oluşturmaktadır.

\section{ANKET FORMUNUN OLUŞTURULMASI VE AMACI}

Anket formumuz oluşturulurken öncelikle Türkçe ve yabancı literatür taranmış ve araştırmanın teorik kısmındaki bilgilerden de yararlanılmış ve araştırmanın amacına yönelik literatür incelenerek bir anket formu oluşturulmuştur. Anketler araştırmaya dahil olan girişimciler ile yapılmıştır. Anket sorularının tespiti için literatür taraması yapılmıştır. Literatür taraması sonucunda, ağlarla ilgili daha önceki gerekçeler tespit edilmiştir. Gerekçeler oluşturulurken geniş bir yazın tarama çalışması yapılmıştır. Bu yazın tarama çalışması sonucunda değişkenler arasındaki ilişkiyi en iyi şekilde ortaya koyabilecek gerekçeler belirlenmeye çalışılmıştır. Gerekçelerde gerekli düzenlemeler ve uyarlamalar yapılarak anket formu hazırlanmıştır. Uygulanan anket formu EK 1'de gösterilmiştir.

Girişimcilerin sosyal ağlara katılma nedenlerinin tespitine yönelik araştırma yapılmıştır. iso ilk 500 sanayi kuruluşu içerisinde yer alan kuruluşların, araştırma kapsamında yer alan yönetim kurulu başkan, yardımcı ve üyelerinden veriler elde edilmiştir. Araştırmada, girişimcilerden elde edilen veriler ile tutumların ölçülmesinde SPSS istatistiksel veri analizinden olan nicel araştırma yönteminden faydanılmıştır. Bilimsel araştırma sürecinin en önemli adımı verilerin analiz edilmesidir. Verilerin analiz edilmesinde, verilerdeki gizli bilgileri keşfetme ve stratejik karar desteği sağlama yönünde ileri analitik çözümler sunan SPSS bilgisayar yazılım programı kullanılmıştır (Bayram, 2009: 1).

Anketimizin birinci bölümünde yer alan ilk beş soru anketi yanıtlayan iş insanları hakkındaki tanımlayıcı ve demografik bilgileri içermektedir. Bu sorular araştırmaya katılan girişimcilerin doğum yerleri, yaşları, cinsiyetleri, eğitim durumları ve yönetim kurulundaki görevlerine ilişkin sorulardır. İlk bölümdeki son dört soru ise araştırmaya dahil olan girişimcilerin işletmelerine ait sorulardır. Bu sorular işletmelerin kuruluş tarihleri, bulundukları sektör, çalışan sayısı ve yıllık net satışlarına ilişkin sorulardır. Anketin ikinci bölümünde ise araştırma önermelerinin sınanması doğrultusunda ağlara katılma nedenlerinin ortaya konması üzerine ilgili yazından oluşturulmuş 10 adet soruyu kapsamakta ve likert tipi 5 'li ölçeğe göre oluşturulmuştur.

Uygulamaya yönelik araştırmamızın amacı, belirlemiş olduğumuz örneklem kitleye anket uygulayarak analiz edebilecek, karşılaştırmalar ve yorumlar yapabilecek bulgulara ulaşmaktır. Uyguladığımız saha anket çalışmasında, araştırmaya katılan girişimcilerin mevcut sosyal ağlarının saptanması ve bu sosyal ağlara katılma nedenlerinin araştırılması yoluyla genellemelere ve sonuca ulaşmak hedeflenmiştir. Saha araştırmaları, doğal ortamlardaki sıradan olayları gözlemler ve araştırmaya bir yönelimdir. Saha araştırmacısı, doğal toplumsal ortamlardaki toplumsal anlamları inceler ve çok sayıda bakış açısını kavrar (Neuman, 2016:548). Anketler araştırmaya dahil olan girişimciler ile yapılmıştır. Literatür taraması sonucunda, ağlarla ilgili daha önceki gerekçeler tespit edilmiştir.

\section{ARAŞTIRMA YÖNTEMI}

Girişimcilerin sosyal ağlara katılmaları önemli bir avantaj yaratabilir. Türk girişimcilerin ağları kullanma biçimlerinin yabancı girişimcilerden ve birbirlerinden farklı olması beklenir. Girişimcilerin ortak yanları, sosyal ağları kullanma biçimleri ve bu ağlara katılma nedenleri araştırmamızda tespit edilmektedir. Literatürde sosyal yerleşiklik kuramı gibi tartışılan girişimciler (veya aktörler) 
ilişki içerisinde oldukları yakın ve uzak çevrelerindeki girişimcilerden, girişimciler de (aktörler de) kendileri için her türlü motivasyon sunan, iktisadi kaynak sağlayan ve yetenek sunan çevreden etkilenir (Top, 2006: 108) görüşleri test edilmektedir.

Araştırmamızın konusu, iso 2019 ilk 500 sanayi kuruluşu içerisinde yer alan Türk girişimcilerin formel ve enformel sosyal ağlara katılma nedenlerinin ortaya konmasıdır. Araştırmamızda sosyal bilimlerde en çok kullanılan veri toplama yöntemlerinden biri olan anket uygulanmıştır. Anketteki ifadeler geniş bir yazın taraması ile oluşturulmuş ve değişkenler arasındaki ilişkiyi en iyi şekilde ortaya koyabilecek ifadeler belirlenmiştir. Literatüre dayalı olarak derlenen ağa katılım gerekçelerinden bir anket formu oluşturulmuş ve Türk iş insanlarına sorulmuştur.

Bu çalışmada araştırma sorusu gereği araştırma yöntemi olarak niceliksel araştırma yöntemi benimsenmiştir. Belirlemiş olduğumuz örneklem grubumuza anketler e-posta yoluyla dağıtılmış ve toplanmıştır. Araştırma sorularını yanıtlamak için toplanan araştırmada verilerin istatistiksel analizinde IBM SPSS Statistics Version 13'ten yararlanılmıştır. Elde edilen veriler SPSS 13.0 istatistik programı kullanılarak analiz edilmiş, tablo ve grafiksel gösterimlerde MS Excell programından yararlanılmıştır. 2019 yılı iso ilk 500 listesinde yer alan, kasti örnekleme yöntemi ile seçilen bu 156 sanayi kuruluşunun yönetim kurulu başkanı, yardımcısı veya üyesi görevlerinde olan 257 girişimciye internet üzerinden e-posta ile ulaşılmış ve 112 girişimciden, girişimcilerimizin sosyal ağlara katılma nedenlerinin tespitine yönelik anketimize geri bildirim alınmıştır. Anket sonuçlarının da SPSS 13.0 programı ile analiz edilmesi sağlanmıştır.

İş insanlarının sosyal ağlara giriş nedenlerinin tespit edilmesi amacıyla, kasti örnekleme yöntemi ile seçilen, iso 2019 ilk 500 sanayi kuruluşu içerisinde yer alan 112 girişimciye uygulanan anket uygulaması ile elde edilen verilerin istatistiki analizleri IBM SPSS Statistics Version 13 ile gerçekleştirilmiştir.

\subsection{Araştırmanın Örneklemi ve Kapsamı}

Araştırmanın ana kütlesini, iso ilk 500 sanayi kuruluşu 2019 yılı listesinde yer alan kuruluşların yönetim kurulu başkan, yardımcı ve üyeleri olan girişimciler oluşturmaktadır. Ticaret bakanlığı onaylı e-imzalı www.belgemodül.com bilgi toplumu hizmetleri adresinden yönetim kurulu başkan, yardımcı ve üyeleri tespit edilmektedir. Merkezi kayıt İstanbul bilgi portal'ı, e-şirket T.T.K'nun 1524 maddesi uyarınca bilgilerin güvenli olarak arşivlendiği elektronik ortamdan faydalanılmıştır.

Araştırmanın kapsamında yer alan iso ilk 500 sanayi kuruluşundan yukarıda belirtilen kısıtlamalar dahilinde 156 sanayi kuruluşu ve 257 Türk girişimci olarak nitelenen yönetim kurulu başkan, yardımcı ve üyeleri araştırmanın kapsamına dahil edilmiştir. 112 iş insanı anketimize geri bildirimde bulunmuştur. Araştırma kapsamında yer alan girişimcilerin ağlara katılma nedenleri, gerçekleştirilen anket ile tespit edilmeye çalışıımış ve SPSS programı ile analizi sağlanmıştır.

Araştırmanın başlıca kısıtlamaları şu şekilde sıralanabilir: sadece iso Türkiye'nin ilk 500 sanayi kuruluşu listesindeki büyük kuruluşların ve Türk iş insanlarının incelenmesi, araştırma için toplanan verinin büyüklüğüne bağlı olarak, veri toplamak zaman alıcı, uygulanması zor bir yöntem olması nedeniyle çoğunlukla anketten yararlanılması, yüzyüze görüşme ve gözlem gibi yöntemlerle desteklenmemesi, anket formlarına verilen cevapların doğruluğunun katılımcıların okuduklarını anlama düzeyleri ile sınırlı kalmaları, ağların kullanma şekillerinin zamanla değişebilmesi, matrislerin oluşturulması sürecinde, belirli bir büyüklüğü aşmaması için bazı ilişkiler araştırma kapsamı dışında bırakılmasıdır.

\subsection{Anketteki İfadelerin Güvenilirliği}

Oluşturulan araştırma modeli çerçevesinde anketler uygulandıktan ve anketlere geri dönüşü sağlandıktan sonra soruların güvenilirlikleri cronbach alfa ile test edilmiştir. Anketteki ifadelerde kullanılan değişkenlerin "güvenilirlik analizi" sonuçları araştırılmıştır. Soru grupları için en yaygın kullanılan içsel güvenilirlik indeksi cronbach alphadır. Bu indeks değişken arasındaki ortalama korelasyonu temel alarak, bir ölçekteki değişkenlerin iç tutarlılığını ölçer. Cronbach alpha değeri 0,70'in üzerinde olan ölçeklerin içsel tutarlılığa sahip olduğu, yani ele alınan ölçeğin güvenilir olduğu söylenir (Bayram, 2009: 194). Güvenilirlik sosyal bilimlerde 0,75-0,80 civarı olması beklenir.

Daha önceden belirlenmiş ölçeğe göre hazırlanmış anketimize verilen yanıtların tutarlılığı güvenilirlik analizi ile ölçülmüştür. Burada tutarlııktan kasıt, ölçeğe uygun olarak sıralanabilir yanıtlar içeren sorulara verilen yanıtların tutarlılı̆ıdır. Güvenilirlik analizi için kullanılan temel analiz cronbach alpha değerinin bulunmasıdır. Tüm sorular için elde edilen alfa değeri o anketin toplam güvenirliğini gösterir ve 0.7 'den büyük olması beklenir. Bu değerden düşük değerler anketin zayıf güvenilirliği olduğunu gösterir. Cronbach tarafından geliştirilen alfa katsayısı yöntemi, maddeler doğru-yanlış olacak şekilde sıralandığında, kullanılması gereken bir iç tutarlılık tahmin metodudur (Öncü, 1994: 49).

Literatür taraması sonucunda oluşturulan anket formunda kullanılan ölçeğin güvenilirliği test edilmiştir. Bu analiz 112 anket katılımcısı ile yapılmıştır. Analizden çıkartılan katılımcı yoktur. Aşağıdaki 'Reliability Statistics' tablosunda, gerekçelerde kullanılan 10 değişkenin ölçülmesi sonucu oluşan cronbach alfa güvenilirlik puanımızın değeri Tablo 1'de yer almaktadır. Aşağıdaki bu tabloda iki tane cronbach alfa değeri görülmektedir. Bu cronbach alfa değerlerinden bir tanesi standardize edilmiş diğeri standardize 
edilmemiştir. Bir tanesi kovaryans matrisine dayanırken diğeri korelasyon temeline dayanır. Biz en soldaki 0,787 değerini kullanıyoruz. Ölçeğimizin cronbach alfa güvenilirlik değeri 0,787 olarak bulunmuştur. Özellikle sosyal bilimlerde kabul edilebilinecek bir değerdir. Sonuç olarak söz konusu "cronbach alfa" değeri yeterince yüksek değerler almış olup, ölçeğin güvenilirliğinin yüksek seviyede olduğu görülmüştür. Böylelikle anket ölçeğimizin, yani kullandığımız ifadelerin oldukça güvenilir oldukları tespit edilmiştir.

Tablo 1: Güvenilirlik İstatistikleri - Cronbach Alfa Değeri Tablosu

\begin{tabular}{|c|c|c|}
\hline Cronbach's Alpha & Cronbach's Alpha Based on Standardized Items & N of Items \\
\hline 0,787 & 0,800 & 10 \\
\hline
\end{tabular}

SPSS'teki 'Item Total Statistics' tablosunda, hangi değişkenimizin, bu güvenilirlik analizine eklenmezse, güvenilirlik değerimizin ne kadar değiştiği, aşağıdaki Tablo 2'de, bu tablodaki 'cronbach's alpha if item deleted' sütununda gösterilmektedir. Aşağıdaki tabloda, 'cronbach's alpha if item deleted' sütunundaki değerler bize, ankette hangi ifadeyi çıkarırsak, cronbach alfa değerimizin yükseleceği veya düşeceğini gösterir. Bu şekilde ölçeğimizin güvenirliği ne kadar yükseliyor yada azalıyor onu görüyoruz. 'Corrected Item - Total Correlation' sütununda negatif değerimiz yok. Burada sadece 5. anket sorusu olan 'rekabet avantajı kazanmak' maddesini silersek, 0,75'i geçemiyor, 0,727'de kalıyor. Fakat sadece bu sütuna bakarak madde silmek çok doğru olmaz. Çünkü kullandığımız gerekçeler, literatürde zaten standartlaşmış ifadelerdir.

Tablo 2: Gerekçelerin Cronbach Alfa Güvenilirlik Değerlerinin Değişimi

\begin{tabular}{|l|c|c|c|c|}
\hline & $\begin{array}{c}\text { Scale Mean if } \\
\text { Item Deleted }\end{array}$ & $\begin{array}{c}\text { Scale Variance if } \\
\text { Item Deleted }\end{array}$ & $\begin{array}{c}\text { Corrected Item- } \\
\text { Total Correlation }\end{array}$ & $\begin{array}{c}\text { Cronbach's Alpha } \\
\text { if Item Deleted }\end{array}$ \\
\hline Sayginlik elde etmek & 31,33 & 28,818 &, 509 &, 763 \\
Nitelikli kaynak saglamak & 32,09 & 28,983 &, 539 &, 758 \\
Yeni pazarlara ve musterilere ulasmak & 30,82 & 31,085 &, 606 &, 755 \\
Hammadde tedariginde etkinlik & 32,31 & 31,280 &, 565 &, 759 \\
Rekabet avantaji kazanmak & 31,71 & 26,426 &, 734 &, 727 \\
Dis cevreden haberdar olmak & 30,70 & 33,547 &, 399 &, 777 \\
Yeni gelismelere, bilgilere, yenilikçi fikirlere & 30,80 & 31,403 &, 543 &, 761 \\
ulasabilmek & & &, 179 &, 805 \\
Ihracat veya diger uluslararasi & 30,91 & 33,776 &, 141 &, 810 \\
faaliyetlerinde avantaj saglayabilmek & 31,21 & 34,224 &, 532 &, 761 \\
Siyasi destek elde etmek & 31,19 & 30,965 & &, \\
Belirsizlikleri, riskleri azaltabilmek & & &, \\
\hline
\end{tabular}

\section{ANKET SONUÇLARININ ANALIZI VE BULGULAR}

Kuramsal nitelikteki bu çalışmada, yapılan anket çalışması ile örgütlerin belirsizlik riski ve meşruiyet kaybı tehlikelerini azaltmak gibi hangi nedenlerle ağlara katıldıkları tespit edilmektedir. Çalışmada öne sürülen gerekçelerin test edilebilmesi için, yönetim kurulu başkan, yardımcı ve üyeleri ile anket sonuçları bir araya getirilerek veri tabanı oluşturulmuştur.

Sosyal ağlara ilişkin literatürde konu edinilen; sosyal sermaye kuramı, yapısal boşluklarda aracılık rolü, sosyal yerleşiklik iddiası, meşruiyet ve güven oluşumunun önemi, aktörlerin sosyal ağlardaki konumu ve merkez çevre ikiliği gibi tartışılan konulara dayanılarak oluşturulan gerekçelerimize ilişkin uyguladığımız anket ile analizi gerçekleştirilmiştir. Araştırma kapsamımızda yer alan 112 katılımcıdan, girişimcilerimizin sosyal ağlara katılma nedenlerinin tespit edilmesine yönelik, 5'li likert ölçeği ile anket uygulaması gerçekleştirilmiş ve SPSS test sonuçları gösterilmiştir.

\subsection{Ankete Katılan Iş̧ İnsanları ve İşletmelerine Dair Özellikler}

Ankete katılan 112 girişimcinin yaş aralığı, cinsiyeti, eğitim durumu ve yönetim kurulundaki görevleri gibi sosyo demografik özellikleri tespit edilmiş ve değerlendirilmiştir. Ankete katılanların yaş aralığı ortalaması, ortancası ve en çok tekrarlanan yaş aralığı modu 50-59 yaş aralığıdır. Katılımcıların \%91,1'inin erkek katılımcı olduğu tespit edilmiştir. Katılımcıların eğitim durumu için, ortalaması 3,04, ortancası 3 ve veri setinde en çok tekrarlanan mod 3 olarak lisans çıkmıştır. Yönetim kurulundaki görev verisi ise 1,60 ortalama, ortancası ve moduda 1 olarak, anket katılımcılarının \%58'inin yönetim kurulu başkanı görevinde oldukları görülmüştür.

Ankete katılan girişimcilerin ilk 500 sanayi kuruluşu içerisinde yer alan işletmelerinin sosyo-demografik özelliklerine ilişkin bazı bilgiler tablolar halinde gösterilmektedir. Ankete katılan girişimcilerin işletmelerinin \%76,8'inin 1990 ve öncesi kurulmuş, \%18'inin 
metal-çelik sektöründe faaliyet gösteren, \%84'ünün 2000 kişi ve altında toplam çalışan sayısına sahip ve yıllık cirosununda \%64,3’ünün, 1.000.000 TL ve altında net satışlara sahip büyük ölçekli sanayi kuruluşları olduğu tespit edilmiştir.

\subsection{Gerekçe ve Anket Test Sonuçları}

Suchman (1995) kurumsal yaklaşıma göre meşruiyetin sosyal olarak inşa edilen bir olgu olduğunu iddia etmiştir. Baum ve Oliver (1991)'e göre ağ ilişkileri meşruiyet kazanmanın bir yolu olarak görülmektedir. Literatürde araştırmalarda güvene dayalı ilişkiler geliştirmenin ve tanıdık refaransların önemine vurgu yapılmıştır. 1. gerekçemizde girişimcilerin, daha fazla saygınlık, toplumsal kabul görmek ve tanınmak gibi stratejik hedeflerle sosyal ağlara katıldıkları gerekçemiz, katılımcıların \%66,1'i tarafından kabul görmüştür. Sosyal ağ ilişkileri, meşruiyet kazanılmasınında bir yolu olarak görülmüştür. Dolayısıyla örgütler için meşruiyet stratejik bir faktör olarak görülmektedir.

Tsai ve Ghosal (1998)'e göre sosyal sermaye, sosyal ilişki ve ağlarda yerleşik olan bir değerdir. 2. gerekçemizde girişimcilerin, örgütlerin kaynak edinimi ve gerekli kilit kaynaklara erişmek için ağlara katıldıkları gerekçemiz, katılımcıların \%57,2'si tarafından kabul görmemiştir. Sadece katılımcıların \%37,5’i tarafından kabul görmüş ve olumlu algılanmıştır.

Gonzalez vd. (2014)'e göre girişimcilerin sosyal ağlarda üyeliği sosyal sermaye yaratır. 3. gerekçemizde girişimcilerin, yeni pazarlara ve müşterilere ulaşmak için sosyal ağlara katıldıkları gerekçe, katılımcıların \%79,5'i tarafından olumlu algılanmış ve kabul görmüştür.

Gulati vd. (2000)'e göre sosyal bağlar güveni artırır ve işlem maliyetlerinin azalmasına yol açabilir. 4. gerekçemizde girişimcilerin, hammadde tedariğinde etkinlik sağlayabilmek için çeşitli dayanışma dernek ve birliklerine, ticaret borsalarına ve iş insanları dernekleri gibi ağlara katılıkları gerekçemiz, katılımcıların \%57,1'i tarafından kabul görmemiştir. Sadece \%11,6'sı tarafından olumlu algılanmış ve kabul görmüştür.

Burt (2004), ağ düzeneğindeki yapısal boşluklardaki aracılık faaliyetlerinin, yani kendisiyle bağlantısı kopuk olan diğer kişilere aracılık faaliyetleriyle bağlanmanın, girişimcilere rekabet avantajı sağladığını iddia etmiştir. 5. gerekçemizde girişimcilerin, rekabet avantajı kazanabilmek, rakiplerine karşı avantajlı konuma geçebilmek için, sosyal ağlara katıldıkları gerekçemiz, katılımcıların \%45,5'i tarafından olumlu algılanmış ve kabul görmüştür. Katılımcıların \%35,7'si tarafından ise kabul görmemiştir.

Granovetter (1985)'e göre aktörler (araştırmamızda girişimciler), bağlamdan bağımsız davranamazlar ve sosyal ilişkiler ekonomik faaliyetler üzerinde etkilidir. 6. gerekçemizde girişimcilerin, dış çevreden haberdar olabilmek, pazarlar, piyasalar ve politikalar hakkında bilgi edinebilmek için sosyal ağlara katıldıkları gerekçemiz, katılımcıların \%86,6'sı tarafından olumlu algılanmış ve kabul görmüştür.

Brass vd. (2004)'e göre ağ yapıları bilgi transferi sağlarlar. 7. gerekçemizde girişimcilerin, yeni gelişmelere, bilgilere, yenilikçi fikirlere ulaşabilmek, takip edebilmek, öğrenebilmek, haberdar olabilmek için sosyal ağlara katıldıkları gerekçemiz, katılımcıların \%81,3'ü tarafından olumlu algılanmış ve kabul görmüştür.

Burt (2001), Freeman (1979) ve Lin (1999) gibi araştırmacılara göre ağ düzenekleri içerisinde girişimcilerin konumları sosyal sermayelerini artırıcı etki yaratır. Burt'a göre aracı konumdaki girişimci köprü görevinden önemli avantajlar elde edebilir. Jaklic (1998)'e göre aktörler (girişimciler) uluslararası ağlara dahil olarak uluslararasılaşmalarını hızlandırma fırsatına kavuşurlar. 8. gerekçemizde girişimcilerin, uluslararasılaşma yolunda avantaj yaratabilmek için ihracat birlikleri ve ticaret borsaları gibi ağlara üye oldukları ve fahri konsolosluklar gibi görevler üstlenebildikleri gerekçemiz, katılımcıların \%69,6'sı tarafından olumlu algılanmış ve kabul görmüştür.

Makro kuramsal yaklaşım temsilcilerinden Biggart ve Hamilton (1992) ve Whitley (2000)'e göre kurumsal bağlamın oluşumunda devletin rolüne dikkat çekilmektedir. Literatürde yerleşik ilişkilerde köprü olarak siyasi bağların kullanıldığından bahsedilmektedir. 9. gerekçemizde girişimcilerin, siyasi destek elde edebilmek ve siyasi gelişmelerden öncelikli olarak haberdar olabilmek için ağlara katıldıkları gerekçemiz, katılımcıların \%68,8'i tarafından olumlu algılanmış ve kabul görmüştür.

Bourdil ve Geraudel (2016)'a göre sosyal ağlardaki bağlar bilgi kaynağı olabilir. 10. gerekçemizde girişimcilerin, belirsizlikleri ve riskleri azaltabilmek ve bilgiye kolay ulaşabilmek için ağlara katıldıkları gerekçemiz, katılımcıların \% $58,1^{\prime} i$ tarafından olumlu algılanmış ve kabul görmüştür.

Belirli bir yapı içerisinde girişimcilerin sosyal ağ bağlantı, ilişki ve temaslarının olumlu etkileri olması beklenir. Aşağıdaki tablodaki aritmetik ortalama değerlerine bakarak, ankete katılan girişimcilerin anket sorularındaki gerekçelerimize ne düzeyde katılıp katılmadıkları ve soruları olumlu veya olumsuz algılama düzeyleri görülebilmektedir. Ortalaması en yüksek olan, daha çok algılanan ve cevap verilen, en çok olumlu değer verilen, en olumlu ilk 3 anket sorusu aşağıdaki Tablo 3'de görüldüğü gibi; 4,09 ortalama ile 'Dış çevreden haberdar olmak', 3,98 ortalama ile 'Yeni gelişmelere, bilgilere, yenilikçi fikirlere ulaşabilmek' ve 3,96 ortalama ile 'Yeni pazarlara ve müşterilere ulaşmak' olarak çıkmıştır. Ortalaması en düşük olan, daha az algılanan, en çok olumsuz değer verilen, 
en olumsuz ilk 3 soru aşağıdaki Tablo 4.8'de görüldüğü gibi; 2,47 ortalama ile 'Hammadde tedariğinde etkinlik', 2,70 ortalama ile 'Nitelikli kaynak sağlamak' ve 3,08 ortalama ile 'Rekabet avantajı kazanmak' olarak çıkmıştır.

Standart sapmanın, ortalamalardan uzaklıklarının düşük olması beklenir. Standart sapmaların ortalamalardan çok yüksek olmasıda, çok düşük olmasıda normal değildir. Dağılım ölçülerinden biri olan standart sapma değerleri, dağılımın hangi şekilde dağıldığını göstermektedir. Standart sapma değeri büyükse, testin ayırt edici özelliği yüksektir, grup hetorejendir, değerler arasındaki fark yüksektir. Aşağıdaki tabloda da görüldüğü gibi ortalaması $(4,09)$ en yüksek olan 'Dış çevreden haberdar olmak' gerekçesi, standart sapması $(0,730)$ en düşük olandır.

Tablo 3: Anket Sorularının Tanımlayıcı İstatistik Değerleri

\begin{tabular}{|c|c|c|c|c|c|c|c|}
\hline \multicolumn{8}{|c|}{ Descriptive Statistics } \\
\hline & $\mathbf{N}$ & Minimum & Maximum & Sum & Mean & Std. Deviation & Variance \\
\hline Saygınlık elde etmek & 112 & 1 & 5 & 387 & 3,46 & 1,280 & 1,638 \\
\hline Nitelikli kaynak sağlamak & 112 & 1 & 5 & 302 & 2,70 & 1,207 & 1457 \\
\hline Yeni pazarlara ve müşterilere ulaşmak & 112 & 2 & 5 & 444 & 3,96 & 0,838 & 0,701 \\
\hline Hammadde tedariğinde etkinlik & 112 & 1 & 5 & 277 & 2,47 & 0,859 & 0,738 \\
\hline Rekabet avantajı kazanmak & 112 & 1 & 5 & 345 & 3,08 & 1,253 & 1,570 \\
\hline Dış çevreden haberdar olmak & 112 & 2 & 5 & 458 & 4,09 & 0,730 & 0,532 \\
\hline $\begin{array}{l}\text { Yeni gelişmelere, bilgilere, yenilikçi } \\
\text { fikirlere ulaşabilmek }\end{array}$ & 112 & 2 & 5 & 446 & 3,98 & 0,870 & 0,756 \\
\hline $\begin{array}{l}\text { İhracat veya diğer uluslararası } \\
\text { faaliyetlerinde avantaj sağlayabilmek }\end{array}$ & 112 & 1 & 5 & 434 & 3,88 & 1,140 & 1,300 \\
\hline Siyasi destek elde etmek & 112 & 1 & 5 & 400 & 3,57 & 1,152 & 1,328 \\
\hline Belirsilikleri, riskleri azaltabilmek & 112 & 1 & 5 & 403 & 3,60 & 0,944 & 0,891 \\
\hline Valid N (listwise) & 112 & & & & & & \\
\hline
\end{tabular}

Friedman testi bize sıralamaların ortalamalarını veren bir sıralama testidir. Aşağıdaki Tablo 4'de, Firedman testi sonucu oluşan gerekçelerin ortalamalarının sıralamaları verilmektedir.

Tablo 4: Gerekçelerin Ortalamalarının ve Kabul Oranlarının Sıralanması

\begin{tabular}{|c|c|c|c|}
\hline Gerekçeler & $\begin{array}{c}\text { Ortalamaların } \\
\text { Sıralanması }\end{array}$ & $\begin{array}{l}\text { Aritmetik } \\
\text { Ortalaması }\end{array}$ & $\begin{array}{c}\text { Olumlu } \\
\text { Kabul Oranı \% }\end{array}$ \\
\hline $\begin{array}{l}\text { 6. Gerekçe - Dış çevreden haberdar olmak } \\
\text { 7. Gerekçe - Yeni gelişmelere, bilgilere, yenilikçi fikirlere } \\
\text { ulaşabilmek } \\
\text { 3. Gerekçe - Yeni pazarlara ve müşterilere ulaşmak } \\
\text { 8. Gerekçe - Ihracat veya diğer uluslararası faaliyetlerinde } \\
\text { avantaj sağlayabilmek } \\
\text { 9. Gerekçe - Siyasi destek elde etmek } \\
\text { 1. Gerekçe - Saygınlık elde etmek } \\
\text { 10. Gerekçe - Belirsizlikleri, riskleri azaltabilmek } \\
\text { 5. Gerekçe - Rekabet avantajı kazanmak } \\
\text { 2. Gerekçe - Nitelikli kaynak sağlamak } \\
\text { 4. Gerekçe - Hammadde tedariğinde etkinlik }\end{array}$ & $\begin{array}{l}6,96 \\
6,81 \\
6,67 \\
6,68 \\
5,81 \\
5,54 \\
5,78 \\
4,44 \\
3,51 \\
2,79\end{array}$ & $\begin{array}{l}4,09 \\
3,98 \\
3,96 \\
3,88 \\
3,57 \\
3,46 \\
3,60 \\
3,08 \\
2,70 \\
2,47\end{array}$ & $\begin{array}{l}\% 86,6 \\
\% 81,3 \\
\% 79,5 \\
\% 69,6 \\
\% 68,8 \\
\% 66,1 \\
\% 58,1 \\
\% 45,5 \\
\% 37,5 \\
\% 11,6\end{array}$ \\
\hline
\end{tabular}




\section{SONUÇ, TARTIŞMA VE ÖNERILER}

Literatürde Burt (1992) gibi bazı araştırmacıların ileri sürdüğü gibi ağ yapısı içerisindeki aktörlerin bağlantıları ve konumlarının rekabet avantajı sağlayabileceği ileri sürüldüğü için iso ilk 500 sanayi kuruluşu içerisinde yer alan girişimcilerin bu ağlara katılma nedenleri araştırılmıştır.

İşletmelerin formel (biçimsel) ve enformel (biçimsel olmayan) ağlara katılarak, meşruiyet kazanma, değişikliklere uyum sağlama, istikrarı koruma, tahmin edilebilirlik sağlama ve aynı zamanda başka işletmelerden öğrenme ve taklit etme yoluyla benzerlik sağlayabildiği literatürdeki güncel ve öne çıkan tartışma konularından biridir. İşletmelerin ağlara katılarak daha fazla kaynağa ulaşma fırsatı yakaladıkları öne sürülmektedir. Ayrıca girişimciler stratejik bir tercih olarak sosyal ağlara katılarak bir sosyal sorumluluk fonksiyonu sağlayarak kendilerini tanıtmalarını ve bilinirliklerinin artırılmalarını sağlayabilmektedirler. Bu ağlara katılım, tanıtım ve pazarlama faaliyetlerinde önemli bir stratejik araç görevi görmektedir.

Çalışmada örgütler arası ağlar konusundaki literatürdeki tartışmalar ışığında, 2019 yılı ilk 500 sanayi kuruluşu içerisinde yer alan işletmelerin Türk girişimcilerinin bu ağlara katılma nedenleri incelenmiştir. Türk girişimcilerin bu ağlara katılma nedenlerinin SPSS 13 programı ile analiz edilmesi sağlanmıştır.

Batı kaynaklı literatürde ağırlıklı olarak işletmelerin ağlara katılmaları ve bir ağ içerisinde yer almalarının kaynaklara erişim, yenilik ve kalite geliştirme gibi konularda stratejik bir rekabet avantajı sağlayacağının öngörüldüğü tespit edilmektedir. Araştırmamızda girişimcilerimizin hangi temel saiklerle ağlara katıldıklarının tespit edilmesine yöneliktir. Araştırma kapsamına alınan girişimcilerin sosyal ağlara katılma nedenlerini belirlemeye yönelik bir anket çalışması uygulanmıştır. Türk iş insanlarının sosyal ağlara katılma nedenlerine ilişkin araştırma sonuçlarımızın Türkiye bağlamında farklılık gösterdiği tespit edilmiştir. Rekabet avantajı kazanmak konulu 5 nolu gerekçemizin, nitelikli kaynak sağlamak konulu 2 nolu gerekçemizin ve hammadde tedariğinde etkinlik sağlamak konulu 4 nolu gerekçemizin ortalamalarının düşük olduğu tespit edilmektedir. Ancak dış çevreden haberdar olmak, yenilikçi fikirlere ulaşmak, yeni pazarlara ve müşterilere ulaşmak, uluslararası faaliyetlerinde avantaj sağlamak, siyasi destek elde etmek, saygınlık elde etmek ve belirsizlikleri azaltmak gibi nedenlerle rekabetçi avantaja dönüştürmek için ağların içinde olmayı tercih ettikleri tespit edilmektedir.

Bu çalışmadan elde edilen bir diğer sonuç ise araştırmamızda girişimcilerimizin hangi temel saiklerle ağlara katıldıklarının tespit edilmesine yöneliktir. Araştırma kapsamına alınan girişimcilerin sosyal ağlara katılma nedenlerini belirlemeye yönelik bir anket çalışması uygulanmıştır. Ankete katılan girişimciler tarafından 4,09 ortalama ve \%86,6 oranında olumlu algı ile en çok olumlu algılanan 6. gerekçemiz olan "Dış çevreden haberdar olabilmek" tir. İkinci en çok kabul gören gerekçe miz ise 3,98 ortalama ve \%81,3 oranında olumlu algı ile 7. gerekçemiz olan "Yeni gelişmelere, bilgilere, yenilikçi fikirlere ulaşabilmek" tir. Üçüncü en çok kabul gören gerekçe miz ise 3,96 ortalama ve \%79,5 oranında olumlu algı ile 3. gerekçemiz olan "Yeni pazarlara ve müşterilere ulaşmak" tır. Girişimcilerimizin sosyal ağlara katılma nedenleri olan belirlediğimiz 10 gerekçemiz içerisinde en az kabul gören ve olumlu algılanan gerekçemiz ise 2,47 ortalama ve sadece \%11,6 kabul oranı ile 4. gerekçemiz olan "Hammadde tedariğinde etkinlik sağlamak" tır.

Ağlara katılma nedenleri araştırmamızın sonuçları, girişimci aktörlerin sosyal ağlarını bilgiye, kaynaklara ve olası fırsatlara ulaşmak için kullandıklarını göstermiştir. Girişimcilerin ağ bağlantılarının sayısının yüksek olması ve ağ ilişkileri içerisinde yer almalarının, sosyal sermayelerinin fazla olmasının beklendiği ve rekabet avantajı için yüksek bir katma değer sağlayabileceği sonucuna varılmıştır. Ayrıca ağ düzeneklerinde girişimcilerin politik güce sahip olmak gibi nedenlerle de, siyasi partilere üye oldukları ve siyasi görevler aldıkları tespit edilmiştir.

Literatürde uluslararası ağlara girmenin girişimcilere, meşruiyet kazandıracağı ve bireysel itibar oluşturulmasına katkı sağlayacağını iddia eden araştırmalarda bulunmaktadır. Ağlara katılma nedenlerine yönelik anket uygulaması sonuçlarından biride, özellikle ihracata yönelik çalışan büyük ölçekli işletmelerin araştırmaya dahil olan girişimcilerin bazılarının uluslararasılaşmak için yerel ve uluslararası ağlara katıldıkları tespit edilmektedir. Anket sonuçlarımız iş insanlarının ağ ilişkilerini uluslararasılaşma yolunda kullandıklarını göstermiştir. Ağlar girişimciler için yeni pazarlara açılmalarında uluslararasılaşma derecelerini artırmalarında, kendileri için fayda sağlayacak kişi veya kuruluşlarla temasa geçmelerinde ve yine bu kişi veya kuruluşların bağlantılarından, tecrübelerinden faydalanmak gibi konularda çok kıymetli bir ilişki kaynağı ve sermayesidir.

Ağlara katılma nedenlerine yönelik anket uygulaması sonuçlarımızdan diğerleri de girişimcilerin riski ve belirsizlikleri azaltmak için saygın kuruluş ve derneklere üye olarak meşruiyet ve itibar aradıklarıdır. Benzer özelliklere sahip girişimcilerin ağ bağlantılarının benzer olması ve benzer sosyal çevrelerde hareket etmeleri beklenir. Girişimciler hedeflerine ulaşmak için kendilerine benzer girişimcilerle birlikte çalışmalarına olanak tanıyan ağlara katılırlar. Araştırma sonuçlarımızda birbirine benzer profildeki iş insanlarının benzer ağlarda yer aldıkları görülmektedir. Bu durum Türk iş insanlarının daha çok iç ilişkiler geliştirdikleri, çünkü kolektivist bir kültürün ve yerel bağlamın etkisinin daha güçlü olduğunu göstermektedir. 
Araştırma sonuçlarımız Gulati (1998: 295)'in ekonomik eylemlerin içinde yerleşik olan bağlamdan etkilendiğini ve bu ekonomik eylemlerin sosyal ağ düzenekleri içerisindeki konumundan etkileneceği yönündeki görüşünü destekler nitelikte çıkmıştır. Türkiye'deki yerleşiklik etkisi, Batı'ya göre farklı saikler ve sonuçlar üretmektedir. Girişimcilerin örgütler arası sosyal ağlarının oluşumunda içinde bulundukları sektörün, devlete olan bağımlııklarının derecesinin ve içinde yerleşik oldukları ortamın etkileri olduğu savunulmaktadır. Türkiye'deki devlet iş insanı ilişkisi batıya göre farklııı gösterdiğinden, içinde bulunulan ağlarda farklılık göstermektedir.

Yüksek katma değerli bir rekabet avantajı elde edilmesinde ağ ilişkilerinin öneminin artacağı ve bu nedenle gelecekte sosyal sermaye ve sosyal ağlar kavramlarının daha da önemli konular haline geleceği düşünülmektedir. Dolayısıyla ileride yapılacak sosyal ağ araştırmalarında girişimcilerin sosyal ağ kullanımları yanında sosyal medya kullanımları da sorgulanmalıdır. Örgüt araştırmalarında sosyal ağ analizlerinin yaygınlaşarak kullanılmasının hem akademik çalışmalara hem de uygulayıcılara yeni bakış açıları sağlaması beklenmektedir. Gelecekte yapılacak çalışmaların, Türkiye bağlamında yerelliğinde etkisini dikkate alan örgütsel ağ yaklaşımlarına katkı sağlayan ve literatürü çeşitlendirecek özgün araştırmaların olması temenni edilmektedir.

\section{REFERANSLAR}

Achrol, R.S., Kotler, P., (1999). Marketing in the network economy. Journal of Marketing, 63, 146-163.

Adler, P., Kwon, S.W., (2002). Social capital: prospects for a new concept. Academy of Management Review, 27(1), 17-40.

Alter, C., Hage, J. (1993). Organizations Working Together. London: Sage.

Anderson, J.C., Narus, J.A., (1991). Partnering as a focused market strategy. California Management Review, 33(3), 95-113.

Axelsson, B., Easton, G., (1992). Industrial networks. a new view of reality. 1. Ed., London and New York: Routledge.

Bae, J., Gargiulo, M., (2003). Partner substitutability and the structure of interfirm relations. Academy of Management Journal, Insead Working Paper Series 2003/51/0B, 1-25.

Baum, J.A.C., Christine, O., (1991). Institutional linkages and organizational mortality. Administrative Science Quarterly, 36(2), $187-218$.

Baum, J.A.C., Rowley, T., (2002). Companion to organizations: an introduction. 1. b., Editors: Joel A.C. Baum, Oxford: Blackwell.

Bayram, N., (2009). Sosyal Bilimlerde SPSS ile Veri Analizi. 2. b., Bursa: Ezgi Kitabevi.

Bikmen, F., Meydanoğlu, Z., (2006). Türkiye'de Sivil Toplum Bir Değişim Süreci, Uluslararası Sivil Toplum Endeksi Projesi, Türkiye Ülke Raporu. İstanbul: Tüsev Yayınları.

Borch, O.J., Arthur, M.B., (1995). Strategic networks among small firms: implications for strategy research methodology. Journal of Management Studies, 32(4), 419-441.

Bourdil, M., Geraudel, M., (2016). What are the interpersonal antecedents of women's network satisfaction?. Gender in Management: An International Journal, 31(4), 266-280.

Brass, D.J., Galaskiewicz, J.J., Greve, H.R., Tsai, W., (2004). Taking stock of networks and organizations: a multilevel perspective. Academy of Management Journal, 47(6), 795-817.

Buğra, A., (1994). State and business in modern turkey: a comparative study. The American Journal of Sociology, 100(3), 1-332.

Buğra, A., (1995). Devlet ve iş adamları. İstanbul: İletişim Yayınları.

Buğra, A., (2001). Kriz ve geleneksel refah rejimi. İstanbul: Boğaziçi Üniversitesi VI. Araştırma Zirvesi.

Buğra, A., (2008). Devlet ve iş adamları. 6. b., Çev., Adaman F., İstanbul: İletişim Yayınları.

Burt, R.S., (1992). Structural holes: the social structure of competition. Harvard University Press.

Burt, R.S., (2004). Structural holes and good ideas. American Journal of Sociology, 110(2), 349-399.

Casson, M., Giusta, M.D., (2000). Entrepreneurship and social capital. International Small Business Journal, $25(3), 220-244$.

Chell, E., Baines, S., (2000). Networking, entrepreneurship and microbusiness behaviour. Entrepreneurship \& Regional Development, $12,195-215$.

Coleman, J.S., (1988). Social capital in the creation of human capital. American Journal of Sociology, 94, 95-120.

Çitçi, U.S., Coşkun, R., (2012). Sosyal ağ kullanımında süreç yaklaşımı: girişimcilerin sosyal ağları kullanımında farklılaşmanın değerlendirilmesi. Selçuk Üniversitesi İktisadi ve İdari Bilimler Fakültesi Dergisi, 12(23), 125-156.

Demirkan, I., Deeds, D.L., (2007). Research collaboration networks and innovation output. Academy of Management Proceedings, 1, 1-6.

Dodd, S., Jack, S., Anderson, A.R., (2002). Scottish entrepreneurial networks in the international context. International Small Business Journal, 20(2), 213-219. 
Dong, D., Gao, X., Sun, X., Liu, X. (2018). Factors affecting the formation of copper international trade community: based on resource dependence and network Theory. Resources Policy, 57, 167-185.

Dowling, J., Pfeffer, J., (1975). Organizational legitimacy: social values and organizational behavior. The Pacific Sociological Review, 18(1), $122-136$.

Dyer, J.H., Singh, H., (1998). The relational view: cooperative strategy and sources of interorganizational competitive advantage. The Academy of Management Review, 23(4), 660-679.

Eisenhardt, K.M., Schoonhoven, C.B., (1996). Resource-based view of strategic alliance formation: strategic and social effects in entrepreneurial firms. Organization Science, 7(2), 136-150.

Freeman, L.C., (1979). Centrality in social networks: conceptual clarification. Social Networks, 1(3), 215-239.

Gargiulo, M., Benassi, M., (2000). Trapped in your own net? network cohesion, structural holes and the adaptation of social capital. Organizaiton Sicence, 11(2), 183-196.

Gonzalez, G.R., Claro, D.P., Palmatier, R.W., (2014). Synergistic effects of relationship managers' social networks on sales performance. Journal of Marketing, 78(1), 76-94.

Gökşen, N.S., Üsdiken, B., (2001). Uniformity and diversity in Turkish business groups: effects of scale and time of founding. British Journal of Management, 12, 325-340.

Gökalp, N., (2003). Ekonomide güven faktörü. Yönetim ve Ekonomi, 10(2), 163-174.

Granovetter, M.S., (1973). The strenght of weak ties. The American Journal of Sociology, 78(6), 1360-1380.

Granovetter, M., (1985). Economic action and social structure: the problem of embeddedness. American Journal of Sociology, 91(3), 481-510.

Gray, B., Wood, D.J., (1991). Collaborative alliances: moving from pratice to theory. Journal of Applied Behavioral Science, $27(1)$, 3-22.

Gulati, R., Gargiulo, M., (1999). Where do interorganizational networks come from? American Journal of Sociology, 104(5), $1439-1493$.

Gulati, R., Nohria, N., Zaheer, A., (2000). Strategic networks. Strategic Management Journal, 21(3), 203-215.

Heper, M. (2015). Türkiye'de Devlet Geleneği. 5. b, Ankara: Doğu-Batı Yayınları.

Hinterhuber, H.H., Hirsch, A., (1998). Starting up a strategic network. Thunderbird International Business Review, 40(3), 185-207.

Huggins, R., (2000). The success and failure of policy-implanted inter-firm network initiatives: motivations, processes and structure. Entrepreneurship and Regional Development, 12(2), 11-135.

Ibarra, H., Hunter, M.L., (2007). How leaders create and use networks. Harvard Business Review, 85(1), 40-47.

Jaklic, M., (1998). Internationalization strategies, networking and functional discretion. Competition \& Change, 3(4), 359-385.

Jarillo, C.J., (1988). On strategic networks. Strategic Management Journal, 9(1), 31-41.

Jarillo, C.J., (1993). Strategic Networks. Oxford: Butterworth-Heinemann.

Jones, C., Hesterly, W., Borgatti, S.P. (1997). a general theory of network governance: exchange conditions and social mechanisms. Academy of Management Review, 22(4), 911-945.

Karagül, M., Masca, M. (2005). Sosyal sermaye üzerine bir inceleme. Ekonomik ve Sosyal Araştırmalar Dergisi, Bahar: 37-52.

Kapucu, N., Montgomery, W.V., (2006). The evolving role of the public sector in managing catastrophic disasters. Administration and Society, 38(3), 279-308.

Kenis, P., Oerlamans, L., (2007). The social network perspective: understanding the structure of cooperation. The Oxford Handbook of InterOrganizational Relations, Oxford University Press, 289-312.

Koç, V., (1983). Hayat Hikayem, 4. b., İstanbul: Apa Ofset.

Lin, N., (1999). Building a network theory of social capital. Connections, 22(1), 28-51.

Lin, N., (2001). Social capital: A Theory of Social Structure. NY: Cambridge University Pres.

Mandjak, T., Simon, J., Szalkai, Z., (2011). A Framework for the analysis of global, regional and local business networks. Industrial Marketing Management, 40(6), 822-829.

Mardin, Ş., (1973). Center-periphery relations: a key to turkish politics? The MIT Press, 102(1), 169-190.

Mardin, Ş., (2003). Din ve ideoloji. İstanbul: iletişim.

Mcpherson, M., Lovin, L.S., Cook, J.M., (2001). Birds of a feather: homophily in social networks. Annual Review of Sociology, 27, 415-444. 
Mizruchi, M.S., Yoo, M., (2002). Interorganizational power and dependence, in Joel A.C. Baum (ed.), Companion to Organizations, New York: Blackwell, 599-620.

Moller, K., Rajala, A., (2007). Rise of strategic nets - new modes of value creation. Industrial Marketing Management, 36(7), 895-908.

Moller, K., Halinen, A., (2017). Managing business and innovation networks-from strategic nets to business felds and ecosystems. Industrial Marketing Management, 67, 5-22.

Nelson, R.E., (1988). Social network analysis as intervention tool: examples from the field. Group and Organization Studies, 13(1), 39-58.

Oliver A.L., Mark, E., (1998). Networking network studies: an analysis of conceptual configurations in the study of inter-organizational relationships. Organization Studies, 19(4), 549-594.

Öberg, C., Shih, T.T.Y., Chou, H.H. (2016). Network strategies and effects in an interactive context. Industrial Marketing Management, 52, $117-127$.

Öncü, H., (1994). Eğitimde ölçme ve değerlendirme. Ankara: Matser Matbaası.

Öniş, Z., Şenses, F., (2007). Küresel dinamikler, ülkeiçi koalisyonlar ve reaktif devlet. ODTÜ Gelişme Dergisi, 34(2), 251-286.

Özen, Ş., Aslan, Z., (2006). İçsel ve dışsal sosyal sermaye yaklaşımları açısından türk toplumunun sosyal sermaye potansiyeli: ortadoğu sanayi ve ticaret merkezi (OSTiM) örneği. Akdeniz i.i.B.F. Dergisi, 12, 130-161.

Park, S.H., (1996). Managing interorganizational network: a framework of the institutional mechanism for network control. Organization Studies, $17(5), 795-824$.

Pfeffer, J., Salancik, G.R., (1978). The external control of organizations: a resource dependence perspective. New York: Harper \& Row.

Perez, V.F., Montes, F.J.L., Morales, V.J.G., (2014). Towards strategic flexibility: social networks, climate and uncertainty. Industrial Management \& Data Systems, 114(6), 858-871.

Perks, H., Kowalkowski, C., Witell, L., Gustafsson, A., (2017). Network orchestration for value platform development. Industrial Marketing Management, 67, 106-121.

Podolny, J.M., Page, K.L., (1998). Network forms of organization. Annual Review of Sociology, 24, 57-76.

Podolny, J.M., (2001). Networks as the pipes and prisms of the market. American Journal os Sociology, 107(1), 33-60.

Pratono, A.H., (2018). From social network to firm performance. Management Research Review, 41(6), 680-700.

Provan, K.G., Milward, B.H., (2001). Do networks really work? a framework for evaluating public-sector organizational networks. Public Administration Review, 61(4), 414-423.

Provan, K.G., Kenis, P., (2007). Modes of network governance: structure, management and effectiveness. Journal of Public Administration Research and Theory, 18(2), 229-252.

Rao, H., Davis, G.F., Ward, A., (2000). Embeddedness, social identity and mobility; why firms leave the NASDAQ and join the New York Stock Exchange. Administrative Science Quarterly, 45(2),268-292.

Ritter, T., Wilkinson, I.F., Johnston, W.J., (2004). Managing in complex business networks. Industrial Marketing Management, 33(3), 175-183.

Robinson, S., (2011). Social networks and entrepreneurial growth. International Journal of Management \& Information Systems, 15(4), $182-187$.

Sargut, S.A., (2003). Kurumsal alanlardaki örgüt yapılarının oluşmasında ve ekonomik işlemlerin yürütülmesinde güvenin rolü. Sosyal Bilimlerde Güven, Ed. Ferda Erdem, Ankara: Vadi Yayınları, 89-124.

Sargut, S.A., Varoğlu, K., Özen, Ş., Oğuz, F., Sözen, C., Yeloğlu, O.H., Sağsan, M., (2007). Ulusal iş sistemi ve örgüt ağları: merkez-çevre ikiliğinin örgütler arası ilişkilere etkisi. Ankara: TÜBITAK 106K174 Nolu Araştırma Projesi.

Suchman, M.C., (1995). Managing legitimacy: strategic and institutional approaches. The Academy of Management Review, 20(3), 571-610.

Sydow, J., Windeler, A., (1998). Organizing and evaluating interfirm networks: a structurationist perspective on network processes and effectiveness. Organization Science, 9(3), 265-284.

Thorelli, H.B., (1986). Networks: between markets and hierarchies. Strategic Management Journal, 7(1), 37-51.

Tsai, W., Ghosal, S., (1998). Social capital and value creation: the role of interfirm networks. Academy of Management Journal, 41(4), 454-476.

Tunçay, S.S., Özer, P.S., (2017). Asil-vekil ilişkilerinin kültürel bağlamda sosyal ağ kuramı çerçevesinde sosyal ağ analizi kullanılarak incelenmesi. İşletme Araştırmaları Dergisi, 9(2): 478-510.

Tüsiad (1991). Türk toplumunun değerleri. İstanbul: TÜSiAD Yayınları.

Uzzi, B., (1997). Social structure and competition in interfirm networks: the paradox of embeddedness. Administrative Science Quarterly, 42(1), 35-67. 
Whitley, R., (2000). The institutional structuring of innovation strategies: business systems, firm types and patterns of technical change in different market economies. Organization Studies, 21(5), 855-886.

Wolf, H.G., Kim, S., (2012). The relationship between networking behaviors and the big five personality dimensions. Career Development International, 17(1), 43-66.

Xie, X., Gao, Y., (2018). Strategic networks and new product performance: the mediating role of ambidextrous innovation. Technology Analysis \& Strategic Management, 30(7), 811-824.

Yeloğlu, H.O., (2005). Ulusal iş sistemlerinde "devlete bağımlılık" kavramı: Türk ulusal iş sistemi üzerine makro kurumsal bir değerlendirme. Marmara Üniversitesi XIII. Ulusal Yönetim ve Organizasyon Kongresi Bildiriler Kitabı, 13-15.

http://bianet.org/biamag/toplum/1916-kriz-ve-geleneksel-refah-rejimi, (10.03.2021).

siviltoplum.gov.tr/derneklerin-faaliyet-alanlarına-gore-dagılımı, (15.04.2021).

siviltoplum.gov.tr/hemsehri-derneklerinin-bolgelere-gore-dağilimi, (15.04.2021).

\section{Ek: Girişimci Sosyal Ağ Anketi}

Literatürde sivil toplum kuruluşları, siyasi partiler, spor kulüpleri, hemşehri dernekleri gibi sosyal oluşumlar sosyal ağ olarak nitelendirilmektedir. Bu araştırmanın amacı, girişimci Türk iş insanlarının hangi amaçlar ve beklentilerle dernek, vakıf, meslek örgütü, oda veya borsa gibi sosyal ağlarda yer aldıklarının tespit edilmesidir. Lütfen bununla ilgili görüşlerinizi, aşağıdaki sorulara önem derecesine göre yanıtlayarak belirtiniz.

\begin{tabular}{|c|c|c|c|c|c|c|}
\hline $\begin{array}{l}\text { SORU } \\
\text { NO }\end{array}$ & SORULAR & 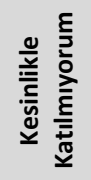 & 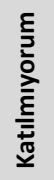 & 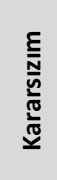 & 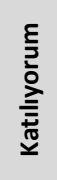 & 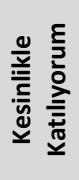 \\
\hline 1. & $\begin{array}{l}\text { Girişimciler saygınlık ve toplumsal olarak kabul görmek, tanınırlık ve bilinirlik elde etmek için } \\
\text { sosyal ağlara katılırlar. }\end{array}$ & & & & & \\
\hline 2. & $\begin{array}{l}\text { Girişimciler nitelikli ve hızlı bir şekilde insan kaynağına ulaşabilmek, daha kolay sermayeye } \\
\text { erişebilmek, maddi destek görebilmek, kriz dönemlerinde krizleri daha kolay atlatabilmek ve } \\
\text { finansal kuruluşlardan daha kolay sermaye edinimi sağlayabilmek için sosyal ağlara katılırlar. }\end{array}$ & & & & & \\
\hline 3. & Girişimciler yeni pazarlara ve müşterilere ulaşabilmek için sosyal ağlara katılırlar. & & & & & \\
\hline 4. & $\begin{array}{l}\text { Girişimciler hammadde malzeme tedariği konusunda etkinlik sağlayabilmek için sosyal ağlara } \\
\text { katılırlar. }\end{array}$ & & & & & \\
\hline 5. & $\begin{array}{l}\text { Girişimciler rekabet avantajı kazanabilmek, rekabette rakiplerine karşı avantajlı konuma } \\
\text { geçebilmek için sosyal ağlara katılırlar. }\end{array}$ & & & & & \\
\hline 6. & $\begin{array}{l}\text { Girişimciler dış çevreden haberdar olabilmek, pazarlar, piyasalar ve politikalar hakkında bilgi } \\
\text { edinebilmek (enforme olmak) için sosyal ağlara katııırlar. }\end{array}$ & & & & & \\
\hline 7. & $\begin{array}{l}\text { Girişimciler sektör, ürünler ve müşteriler ile ilgili yeni gelişmelere, bilgilere, inovatif (yenilikçi) } \\
\text { fikirlere ulaşabilmek, takip edebilmek ve öğrenebilmek amacıyla, sektördeki en iyi } \\
\text { uygulamaları görmek, tanımak, rakiplerinin veya diğer işletmelerin başarılı neler } \\
\text { yaptıklarından, başarılı uygulamalarından haberdar olabilmek için sosyal ağlara katııırlar. }\end{array}$ & & & & & \\
\hline 8. & $\begin{array}{l}\text { Girişimciler ihracat veya diğer uluslararası faaliyetlerinde avantaj yaratabilmek için sosyal } \\
\text { ağlara katılırlar. }\end{array}$ & & & & & \\
\hline 9. & $\begin{array}{l}\text { Girişimciler siyasi destek elde etmek veya siyasi gelişmelerden öncelikli olarak haberdar } \\
\text { olabilmek için sosyal ağlara katılırlar. }\end{array}$ & & & & & \\
\hline 10. & $\begin{array}{l}\text { Girişimciler belirsizlikleri ve riskleri azaltabilmek, bilgiye daha kolay ulaşabilmek için sosyal } \\
\text { ağlara katılırlar. }\end{array}$ & & & & & \\
\hline
\end{tabular}

